Portland State University

PDXScholar

1978

\title{
Petrology of the Bull-of-the-Woods intrusive complex
}

James Streshley Jackson

Portland State University

Follow this and additional works at: https://pdxscholar.library.pdx.edu/open_access_etds

Part of the Geology Commons

Let us know how access to this document benefits you.

\section{Recommended Citation}

Jackson, James Streshley, "Petrology of the Bull-of-the-Woods intrusive complex" (1978). Dissertations and Theses. Paper 2960.

https://doi.org/10.15760/etd.2905

This Thesis is brought to you for free and open access. It has been accepted for inclusion in Dissertations and Theses by an authorized administrator of PDXScholar. Please contact us if we can make this document more accessible: pdxscholar@pdx.edu. 
AN ABSTRACT OF THE THESIS OF James Streshley Jackson for the Master of Science in Geology presented August 22, 1978.

Title: Petrology of the Bull-of-the-Woods Intrusive Complex APPROVED BY MEMBERS OF THE THESIS COMMITTEE:

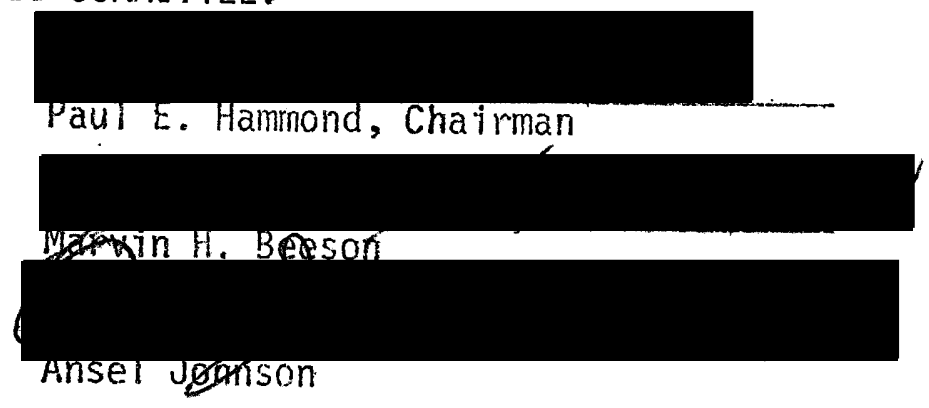

The Bull-of-the-Woods intrusive complex consists of a cluster of dikes, sills, and irregular stocks, ranging in composition from pyroxene and/or hornblende andesite, dacite, diorite, to quartz diorite. These intrusions were emplaced at shallow depth within the Sardine Formation, which consists of a $600-\mathrm{m}$ thick lower tuft unit and a 146-m thick upper andesite flow.

The host rock is metamorphosed in a zone $5 \mathrm{~m}$ wide around the intrusions to the albite-epidote hornfels facies. Major and trace element concentrations in the intrusive rocks are typical of andesites. Concentrations range from:

1.72-3.10 percent weight $\mathrm{Na} ; 3.27-5.57$ percent weight Fe; 8-140 ppin Cr; 14.5-29.6 ppm Co; 11.44-21.00 ppm Sc; 10-17 ppm Rb; 13-29 ppm La; 2.2-6.4 ppm Sm; 0.91-1.68 ppm Eu; 21.58 ppm Sm; 170-900 ppm Ba; $1.0-7.6$ ppm Th; 0.18-0.w0 ppm Lu; and 1.6-6.7 ppm Hf. 
The narrow range of rare earth elements and the ratios of $\mathrm{Fe} / \mathrm{Co}$ and $\mathrm{Fe} / \mathrm{Sc}$ indicate that these rocks are comagmatic. The range of Sc is distributed in concentric, geographic zones of low, medium, and high concentrations through the area suggesting that mild gravity differentiation occurred in the parent magma body. The units were intruded along fissures in the host rock by forceful injection. The fine-grained rocks preceded intrusion of the coarse grained rocks, as indicated by crosscutting relationships. Broad, gentle deformation and propylitic alteration of the host rock suggests that a stock underlies the area. 
PETROLOGY OF THE BULL-OF-THE-WOODS INTRUSIVE COMPLEX

\author{
by \\ JAMES STRESHLEY JACKSON
}

A thesis submitted in partial fulfillment of the requirements for the degree of

MASTER OF SCIENCE

in

GEOLOGY

Portland State University

1979 
TO THE OFFICE OF GRADUATE STUDIES AND RESEARCH:

The members of the Committee approve the thesis of James S. Jackson presented August 28, 1978.

Pâul E. Hammond, Chậrman

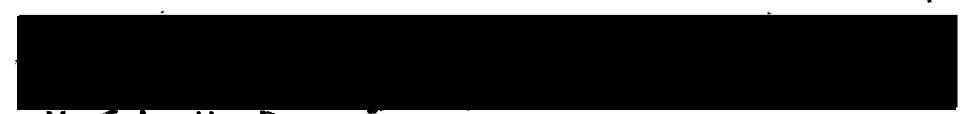

Marvin H. Beeson

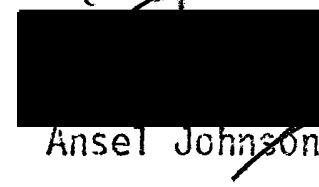

APPROVED:

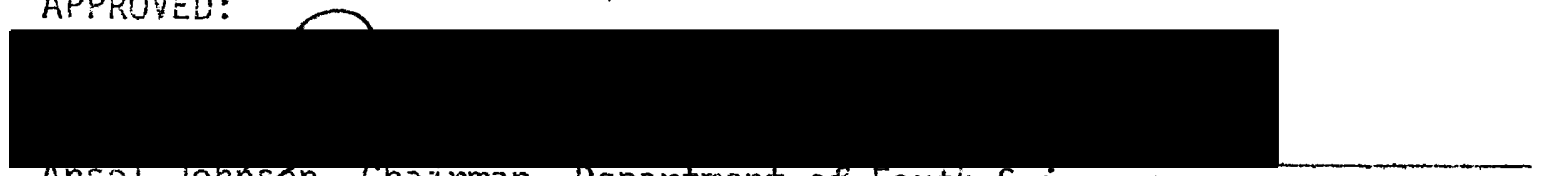

Anse! Jomison, Chatrman, Department of Earth Sciences

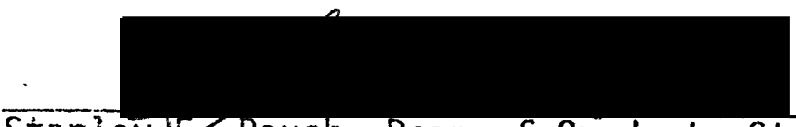

Stanley 


\section{ACKNOWLEDGEMENTS}

The author is grateful for the financial assistance of a Research Grant from the Mazamas Research Committee.

Dr. Paul Hammond of Portland State University suggested the project and was of great assistance in the initial phases of field work, and throughout the course of study. Dr. M. H. Beeson, Dr. A. G. Johnson, and Dennis Nelson made many helpful suggestions in the course of writing of the thesis. Fred Gullixson and Mike Moran assisted me in the various phases of sample preparation for thin sections and neutron activation analysis. 
TABLE OF CONTENTS

PAGE

ACKNOWLEDGEMENTS .................................

LIST OF FIGURES . . . . . . . . . . . . . . . . vii

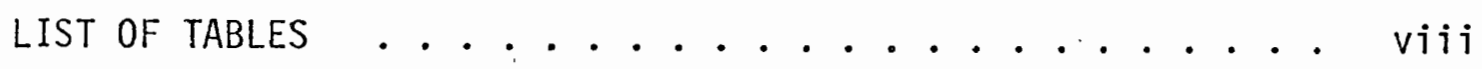

CHAPTER

I INTRODUCTION ...................... 1

PURPOSE ......................... 1

STUDY AREA . . . . . . . . . . . . . . 2

METHODS OF INVESTIGATION . . . . . . . 2

PREVIOUS WORK ............. 3

II GEOLOGIC SETTING ................ 4

III ROCK UNITS . . . . . . . . . . . . . 6

STRATIFIED ROCKS ........... . . 6

Sardine Formation ......... 6

Tuff of Pansy Basin $\left(\right.$ Tsa $\left._{1}\right) \ldots \ldots$
Hornblende Ignimbrite

of North Dickey Peak $\left(\mathrm{Tsa}_{2}\right) . \ldots .8$

Andesite Lava Flows of

Schreiner Peak $\left(\mathrm{Tsa}_{3}\right)$...... 9

Hornblende Andesite 3 Mountain ( $\left.\mathrm{Tsa}_{4}\right)$. .

Quaternary Deposits . . . . . . . 10

Glacial Drift (Qt) . . . . . . 11

Landslides (Q1s)........... 12

Alluvium (Qal)............. 12 
INTRUSIVE ROCKS ...........13

Introduction .....................

Pyroxene Andesite Porphyry of

Big Slide Mountain (Tipa). . . . . 17

Pyroxene-Hornblende Andesite

Porphyry of Mother Lode

Mountain (Tipha) ........ 18

Hornblende Andesite Porphyry of

Bul1-of-the-Woods (Tiha) ...... 19

Hornblende Quartz Diorite

Porphyry of Twin Lakes (Tigd). . . . . 20

Hornblende Diorite of Elk Lake

Creek (Tihd) ...........21

Pyroxene-Hornblende Dacite Porphyry of

South Dickey Peak (Tidc) . . . . . . 21

Hornblende-Quartz Diorite of

Pansy Mountain (Tid) ......... 22

Summary and Discussion ........23

IV MAJOR AND TRACE ELEMENT GEOCHEMISTRY ...... 25

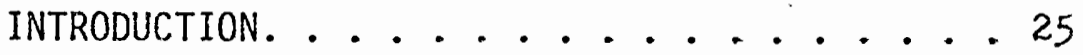

INTRUSIVE LITHOLOGY GEOCHEMISTRY . . . . . 28

COMPARATIVE PETROLOGY . . . . . . 38

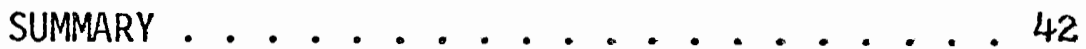

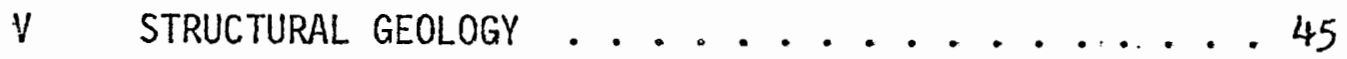

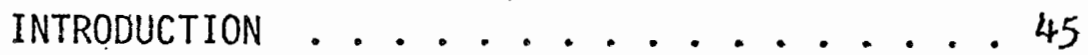

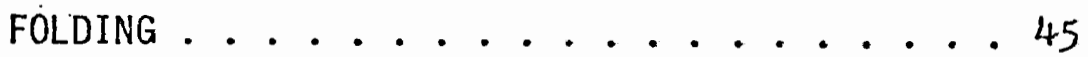

FAULTING ...................... 46

INTRUSIONS ......................

BATHOLITH ................ 48

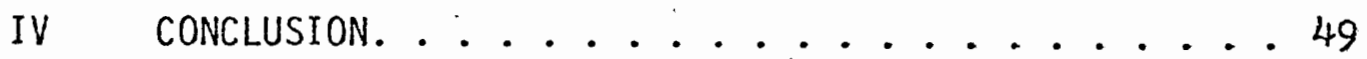

PETROGRAPHY .................... 49

GEOCHEMISTRY ..................... 49 
CHAPTER

EMPLACEMENT OF INTRUSIONS ........ 50

MECHANISM OF INTRUSION ........... 51

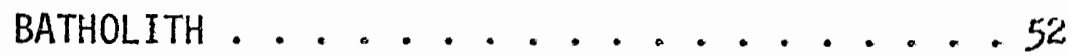

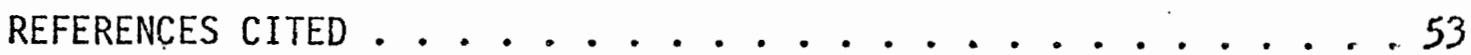

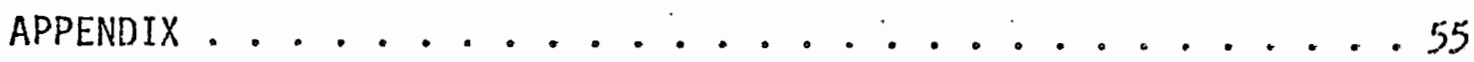




\section{LIST OF FIGURES}

FIGURE

PAGE

1. Summary of Stratified Rocks in the Bull-of-theWoods Area

2. Summary of Intrusive Andesite Porphyry and Diorite Porphyry Characteristics . . . . . 14

3. Summary of Intrusive Diorite and Dacite Characteristics. . . . . . . . . 15

4. Major and Trace Element Abundances in Rocks . . . 26

5. Major and Trace Element Abundances in Bul1-ofthe-Woods Intrusive Rocks . . . . . . . . 37

6. Covariation of Iron and Cobalt in Bull-of-theWoods Intrusive Rocks . . . . . . . . . 40

7. Covariation of Iron and Scandium in Bull-ofthe-Woods Intrusive Rocks . . . . . . . 41

8. INAA Sample Locations by Rock Type, Showing Areas of Low, Average, and High Sc , . Concentrations ............... . . 43 


\section{LIST OF TABLES}

TABLE

PAGE

I

Modal Analyses of Representative Intrusive Rocks • . 16

II Major and Trace Element Concentrations in the Andesite Porphyry of Big Slide Mountain . . . . 29

II - Concentrations in the Andesite Porphyry of Mother Lode Mountain ........... . 30

IV Concentrations in the Andesite Porphyry of Bul1of-the-Woods ............. 31

$\checkmark \quad$ Concentrations in the Quartz Diorite Porphyry of Twin Lakes . . . . . . . . . . 32

VI Concentrations in the Diorite of Elk Lake Creek . . . 33

VII Concentrations in the Dacite Porphyry of South Dickey Peak. . . . . . . . . . . . . 34

VIII Concentrations in the Quartz Diorite of Pansy Mountain ............. . . 35 


\section{CHAPTER I}

INTRODUCTION

\section{PURPOSE}

An area of unmapped intrusions lies within the BuTl-of-the-Woods Roadiess Area of Mount Hood National Forest. A variety of andesites, dacites, and diorites intruding units of tuff and andesite lava flows crop out over an area of $52 \mathrm{sq} \mathrm{km}$. These intrusions do not appear on the Geolonic Map of Oregon West of the 121st Meridian (Wells and Peck, 1961). The purpose of this investigation is to map and describe these intrusions, with attention to the following questions:

What is the petrographic and geochemical nature of these intrusions?

What is the order of emplacement of these intrusions?

What is the probable mechanism of intrusion?

What relation do these intrusions bear to a possible underlying batholith?

Contact relations in the field, petrographic studies, and major and trace element trends were used to address these questions. 


\section{STUDY AREA}

The Bul1-of-the-Woods Roadless Area is located in northern Marion County, $88 \mathrm{~km}$ southeast of Portland, Oregon (Index Map, Plate 1). Main access to the area is via U. S. Forest Service Road S-63, $21 \mathrm{~km}$ from its junction with Oregon 224 at Ripplebrook. Severa.l logging roads lead to trails which traverse the area. Access from the south is via U. S. Forest Service Road S-80 at Elk Lake. Road S-80 is reached via S-46, $7 \mathrm{~km}$ from its junction with Oregon 22 at Detroit.

The area extends from North Dickey Peak and Schreiner Peak south to Twin Lakes, and from Pansy Basin east to Elk Lake Creek (Plate 1). No roads enter the study area though it is accessible by a system of trails. The best outcrops occur along ridge tops, about $1300 \mathrm{~m}$ elevation. Outcrops in the valleys are rare and limited in area due to dense forestation.

\section{METHODS OF INVESTIGATION}

Field work was conducted during the summer and fall of 1977. The geology was plotted on a .topographic base map scale 1:24000, enlarged from the Battle Ax 15 minute quadrangle.

Representative samples were collected and analyzed petrographically and chemically. Mineral identifications were based on optical properties observed with a petrographic microscope. 
Plagioclase composition was determined using the tables of Tobi and Kroll (1975). Mafic minerals were determined using Durrell (1949) and Deer, Howie, and Zussman (1966). Mineral modes were determined by point counting representative slides. Rock names were assigned using Streckeisen (1973) and Jackson (1970). Major and trace element abundances were determined through neutron activation analysis (Gordon, et a1. 1968). Samples were crushed to pass through à 300 mesh sieve until 16 grams of each sample were obtained. The fine powder was split into one gram samples that were placed in clean poly-vials. The samples and a standard, BCR-1, prepared by the USGS were irradiated at the Reed College TRIGA reactor in a neutron flux for one hour. The samples and standard were weighed after 7 days, placed in clean poly-vials, and then counted after 7 and 19 days in a high resolution $\mathrm{Ge}(\mathrm{Li})$ detector and multichannel analyzer. Activity peaks were analyzed from the resulting spectra by the Portland State PDP-1I computer, and then a Fortran program on the Portland State Harris computer calculated elemental abundances by comparing the activities of the unknown samples with the known standard.

\section{PREVIOUS WORK}

Thayer $(1937,1939)$ was the first to map near the area. Although his text noted the presence of dikes and intrusions, he plotted none on his final map (Thayer, 1937): Peck et al (1964) performed reconnaissance mapping in the area, but again indicated no intrusive rocks. Dyhrman (1975) mapped the area immediately west of the study area. 


\section{GEOLOGIC SETTING}

The study area lies within the Western Cascade physiographic province. This province, which is characterized by deep valleys separated by long, narrow ridges, lies in a north-south belt east of the Willamette Valley and west of the High Cascades. Relief throughout the province is $900 \mathrm{~m}$. The area annually receives 1700 $\mathrm{mm}$ precipitation, mostly in the winter as snow and rain (Moir et al, 1973). The lower slopes of the province are heavily timbered with Douglas fir, western red cedar, and an understory of alder and rhododendron. The principal geologic processes in the province have been volcanism followed by extensive glaciation. Peck et al (1964) report the geologic history of the province as a sequence of volcanic deposition, folding, intrusion, and erosion. The Little Butte Volcanic Series was erupted during the 01 igocene. The Columbia River Basalt flowed into the province from vents to the east during the middle Miocene. The Sardine Formation, consisting of a lower unit dominated by tuffs and an upper unit dominated by lava flows, erupted in the late Miocene. Gentle folding of the Western Cascade province occurred after the deposition of the Sardine and before the emplacement of intrusions. Eruption of the High Cascade units occurred in the Plio-Pleistocene. Glaciation occurred in the Western Cascades province during the Quaternary. 
The present study seeks to map in detail an area of intrusive rocks within the Western Cascades. The host rock consists of two tuff units and an andesite lava flow sequence mapped as the Sardine Formation by Peck et al (1964). Within the study area, these units form a broad anticline defined by Peck. Seven intrusive lithologies have been identified within the area. Ouaternary deposits overlie both the host and intrusive rocks. Glacial drift is found in all valleys at lower elevations and in small deposits in cirque basins above $1400 \mathrm{~m}$ elevation. Lands]iding occurs throughout the area at lower elevations, and is extensive in areas underlain by tuff. Streams with steep gradients are presently reworking all units. 


\section{CHAPTER III}

ROCK UNITS

\section{STRATIFIED ROCKS}

Stratified rocks in the Bull-of-the-Woods area total $800+\mathrm{m}$ thickness. They are assigned late Miocene and Quaternary ages by Peck et al (1964). The Tate Miocene Sardine Formation consists of three informal members: A tuff, an ignimbrite, and a series of andesite lava flows (Figure 1). The Quaternary deposits are divided into three units: glacial drift, landslide debris, and alluvium. The Quaternary units overlie both the Sardine Formation and the intrusions.

The following discussion is ordered from oldest to youngest. In accordance with the Code of Stratigraphic Nomenclature (AAPG, 1970), names of specific geographic features in the study area have been used to designate informal units.

\section{Sardine Formation}

Tuff of Pansy Basin (Tsa ${ }_{1}$ ). The lowest exposed unit in the study area consists of light brownish grey, weathering brown, pumiceous-1ithic-crystal-vitric tuff. Major outcrops occur in the Pansy Basin and above large landstides on the north side of the area (Plate 1). Its maximum exposure is below South Dickey Peak in Pansy Basin where it is $120 \mathrm{~m}$ thick. This unit underlies all of 


\begin{tabular}{|c|c|c|c|c|c|}
\hline \multicolumn{2}{|c|}{ Age } & Formation & Lithology & Thitckness & Description \\
\hline & & 1 & $1+m$ & Stream Deposits. Q2I \\
\hline & & & b & $25+m$ & $\begin{array}{c}\text { Landslide Deposits. } \\
\text { QIs }\end{array}$ \\
\hline & & & 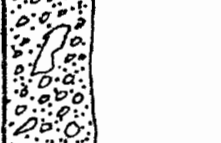 & $10+m=$ & Glacial Drift. Qi \\
\hline \multirow{4}{*}{ 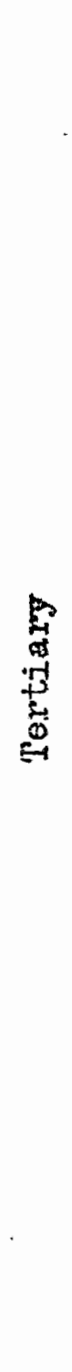 } & \multirow{4}{*}{ 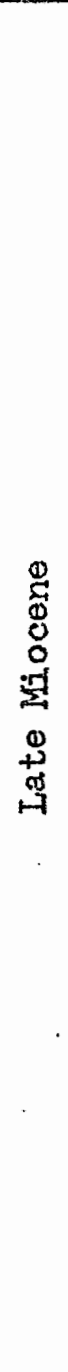 } & \multirow{4}{*}{ 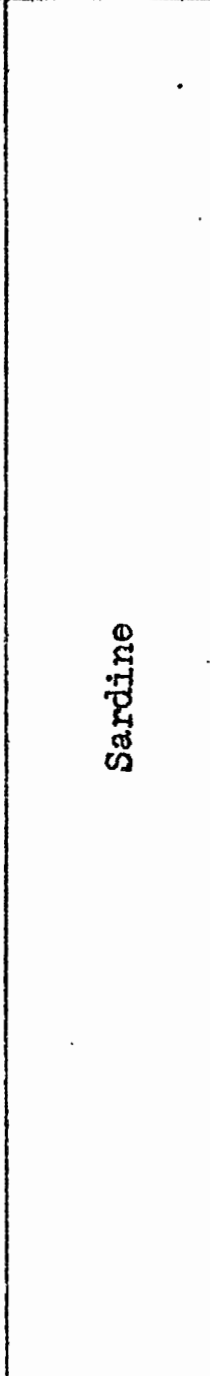 } & 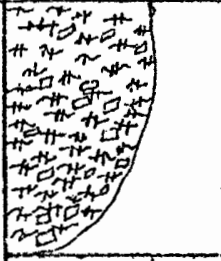 & $99+\mathrm{m}$ & $\begin{array}{l}\text { Intra-cangron horm- } \\
\text { blende andesite lava } \\
\text { flow at Silver King } \\
\text { Mountain. Tsa } 4\end{array}$ \\
\hline & & & 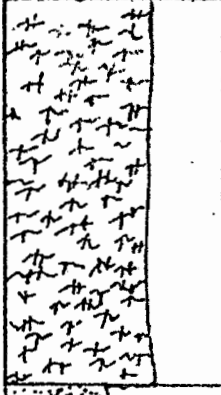 & $146+m$ & $\begin{array}{l}\text { Four andesite lava } \\
\text { flows accurring on } \\
\text { peaks in norti part } \\
\text { of area. Lowest flon } \\
\text { has plagioclase } \\
\text { phenocrysts. Upper } \\
\text { flows have pyroxene } \\
\text { phenocrysts. isa. } 3\end{array}$ \\
\hline & & & 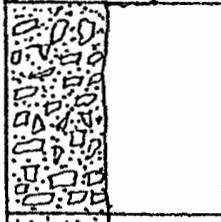 & $90+m$ & $\begin{array}{l}\text { Light greenish-groy, } \\
\text { pumiceous, hornblends } \\
\text { crystal-iithic-vitrie } \\
\text { tuff on N. Dickey Pk. } \\
\text { isa2 }\end{array}$ \\
\hline & & & 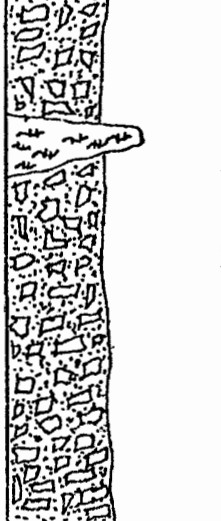 & $\begin{array}{l}5-30 \mathrm{~m} \\
600+m\end{array}$ & $\begin{array}{l}\text { Interstratified } \\
\text { Hornblende andesi.te } \\
\text { lava flow on Big } \\
\text { Slide Mountain. } \\
\text { Light bromish-grey, } \\
\text { puniceous lithic- } \\
\text { crystal-vitrio tuff. } \\
\text { Tsa }{ }_{1}\end{array}$ \\
\hline
\end{tabular}

Figure 1: Summary of stratified rocks in the Bull-of-the-Woods 
the study area, and is the most extensive mapped unit. Its base is not exposed in the study area, and its maximum estimated thickness is $600 \mathrm{~m}$. It is interstratified with one andesite lava flow, best exposed on the east face of Big Slide Mountain. It is conformably overlain by a series of andesite lava flows and an ignimbrite, and it is unconformably overlain by one intracanyon andesite lava flow. The tuff of Pansy Basin underlies gentle slopes; it is subject to massive landsliding. Outcrops show thin slabby jointing.

The rock is composed of 10 percent pumice fragments, up to 1 $\mathrm{cm}$ in diameter. Aphanitic, lithic fragments of, angular dark grey andesite and basaltic andesite, 1 to $3 \mathrm{~cm}$ diameter, compose 20 percent of the rock. Whitish, altered crystals of twinned plagioclase compose 15 percent of the rock. Altered mafic crystals, 1 to $3 \mathrm{~cm}$ diameter, resembling hornblende, compose 5 percent of the rock. The remaining 50 percent of the rock is altered vitric matrix.

A cliff-forming, platy jointed hornblende andesite lava flow is interstratified with the tuff of Pansy Basin on the north flanks of Big Slide Mountain and Schreiner Peak. The flow is in conformable contact with underlying and overlying tuff. It has a maximum exposed thickness above Dickey Creek of $30 \mathrm{~m}$, and thins to $5 \mathrm{~m}$ south along the east face of Big Slide Mountain. The rock is light green-grey, weathering dark grey. It is composed of 10 percent white plagioclase phenocrysts, and 5 percent greenish-black, $2 \mathrm{~mm}$ long, hornblende phenocryst set in a glassy groundmass.

Hornblende Ignimbrite of North Dickey Peak $\left(\underline{T s a}_{2}\right)$. A slabby 
jointed, light greenish-grey, weathering brownish grey, pumiceous crystal-lithic-vitric welded tuff conformably overlies the tuff of Pansy Basin at North Dickey Peak (Plate 1). This member of the Sardine Formation is distinguished from the underlying tuff member by two characteristics: Hornblende crystals $2 \mathrm{~cm}$ long, and partial welding of the vitric matrix. The unit is estimated to be $90 \mathrm{~m}$ thick at North Dickey Peak; it is Qverlain by no other unit. Its extent is restricted to North Dickey Peak, where it is a cliff former.

Compressed pumice fragments compose 20 percent of the rock. The hornblende crystals compose 10 percent of the rock, and plagioclase lathes $2 \mathrm{~mm}$ long compose 20 percent of the rock. Lithic fragments of pliagioclase andesite porphyry compose 5 percent of the rock. The remaining 45 percent of the rock is composed of partially welded vitric groundmass.

\section{Andesite Lava Flows of Schreiner Peak $\left(\underline{\mathrm{Tsa}}_{3}\right)$. A series of} four andesite lava flows are limited in extent above 1610-m elevation on the north side of the area at Schreiner Peak, Knob Peak, and Big Slide Mountain (Plate 1 ). The stratigraphically lowest flow is a 15 m thick plagioclase andesite, which lies directly upon the tuff of Pansy Basin. The flow is platy jointed, and forms a cliff $10 \mathrm{~m}$ high. It erodes to form a steep talus slope below the cliff. In hand specimen, the rock is medium grey, weathering reddish-grey. Flow aligned white plagioclase lathes $2 \mathrm{~mm}$ long compose 15 percent of the rock. Stubby black pyroxene prisms $1 \mathrm{~mm}$ long compose 5 percent of the rock. Vesicles $2 \mathrm{~mm}$ in diameter are scattered throughout the 
flow. Three pyroxene andesite lava flows lie comformably upon the plagioclase andesite flow. All three flows have the same lithology, and at their greatest exposed thickness on Schreiner Peak they are $60 \mathrm{~m}$ thick. No unit lies upon these flows within the study area. These flows form a cliff $25 \mathrm{~m}$ high, and erode to form a steep talus s7ope. In hand specimen, the rock is dark grey, weathering dark brownish-grey. Stubby pyroxene prisms $1 \mathrm{~mm}$ long compose 10 percent of the rock. Needles of plagioclase $1 \mathrm{~mm}$ long compose 15 percent of the rock. Compressed vesicles $1 \mathrm{~mm}$ long occur throughout all three flaws.

Hornblende Andesite Lava Flow of Silver King Mountain (Tsa 4 ). One lava flow of hornblende andesite porphyry forms the summit cliffs of Silver King Mountain in the southwestern part of the area (Plate 1). Although its base is not exposed, the flow appears to fill a north-sloping canyon up to $97 \mathrm{~m}$ deep cut into the underlying tuff of Pansy Basin. The flow is platy jointed in its lower portion, grading upward in $3 \mathrm{~m}$ to an upper zone of hackly jointing. In hand specimen, the rock is medium grey, weathering light grey to brown. Phenocrysts of hornblende, up to $5 \mathrm{~mm}$ long, disposed in subparallel alignment, are the distinctive feature of this unit. Hornblende composes 20 percent of the rock; plagioclase lathes in glomeroporphyritic clusters compose 25 percent of the rock. The remaining 55 percent of the rock is composed of glassy aphanitic groundmass.

\section{Quaternary Deposits}

The effects of three types of erosion are visible in the area. U-profiles in major valleys, and small. cirque basins on the north sides 
of ridges above $1440 \mathrm{~m}$ elevation, indicate the effects af glaciation; 'drunken forests', rotated slump blocks and steep slopes mantled with broken boulders indicate active landsliding, slumping, and creep. $V$-profiles on the flanks of valley walls, graded deposits, and point bars are the effects of stream action. Erosion has produced three types of Quaternary deposits which have been mapped in the area: glacial drift (Qt), landslides (Qls), and alluvium (Qai).

Glacial Drift (Qt). A ground moraine blankets much of the Elk Lake Creek valley. Poorly sorted, anguiar clasts of tuff and andesite are supported in a matrix of silt and sand. The clasts are fresh and range from 10 to $70 \mathrm{~cm}$ in diameter. Rare boulders up to $3 \mathrm{~m}$ in diameter are found at the lowest elevations of the drift within the study area.

A ground moraine of similar material mantles the upper reaches of Mother Lode Basin. Mother Lode Creek has dissected the drift to a depth of $2 \mathrm{~m}$ without reaching bedrock. The drift in Twin Lakes Basin is also poorly dissected by streams to a depth of $2 \mathrm{~m}$ without reaching bedrock.

The ground moraine in Pansy Basin is less dissected than in either Mother Lode Basin or Elk Lake Creek valley. It is overlain by landslide debris on the west side (Plate 1). The moraine is composed of abundant clasts of tuff supported by a matrix of sand and silt. Drift mantles the Dickey Creek valley and Welcome Lake Basin divide at an elevation of $.1463 \mathrm{~m}$. Isolated deposits of drift occur in both basins, and in several cirque basins located on the north side of major ridges in the area. (Plate 1). 
Landslides (Q1s). Landslide debris is extensive throughout the study area's lower valleys. These slides commonly occur on tuff of Pansy Basin; the largest slides are shown on Plate 1. Recentiy active slides produce areas of bare ground, slumping and destruction of live trees.

Alluvium (Qal). All streams in the area have steep gradients and are incising narrow, $V$-shaped gorges. These streams are reworking all other deposits in the area, producing graded point bars and small deltas at stream junctions. 


\section{INTRUSIVE ROCKS}

\section{Introduction}

Andesite, dacite, and diorite rocks intrude the Sardine Formation in the study area as dikes, sills, and irregular stocks (Figures 2 and 3). Andesite dikes are most abundant: they occur through $1585 \mathrm{~m}$ etervation and trend N. $60^{\circ} \mathrm{E} ., \mathrm{N} .10^{\circ} \mathrm{W}$, and N. $45^{\circ} \mathrm{W}$. Dacite stocks, dikes and sills occur below $1585 \mathrm{~m}$ elevation, and show no preferred orientation. Diorite sills and dikes occur below 1340 m elevation. Intrusive rocks are ridge and cliff formers (Figures 2 and 3 ). The andesites are blocky jointed, while the diorites are slabby" jointed. The andesites form steep talus slopes and the diorites erode to form pebbly soil.

Contacts between the intrusive and host rocks are poorly exposed. The host rock is usually brecciated and subject to contact metamorphism of the albite epidote facies for a distance of no more than $5 \mathrm{~m}$ from the contact. Quartz veins within the host rock are occasionaily found near intrusions.

The rocks are composed of plagioclase, hornblende, pyroxene, and quartz. Plagioclase ranges from 62.1 to 80.6 percent volume of the rock; hornblende ranges from 1.3 to 22.4 percent volume; pyroxene ranges from 1.3 to 16.0 percent volume; and quartz ranges from 2.8 to 6.4 percent volume of the rock (Table I). 


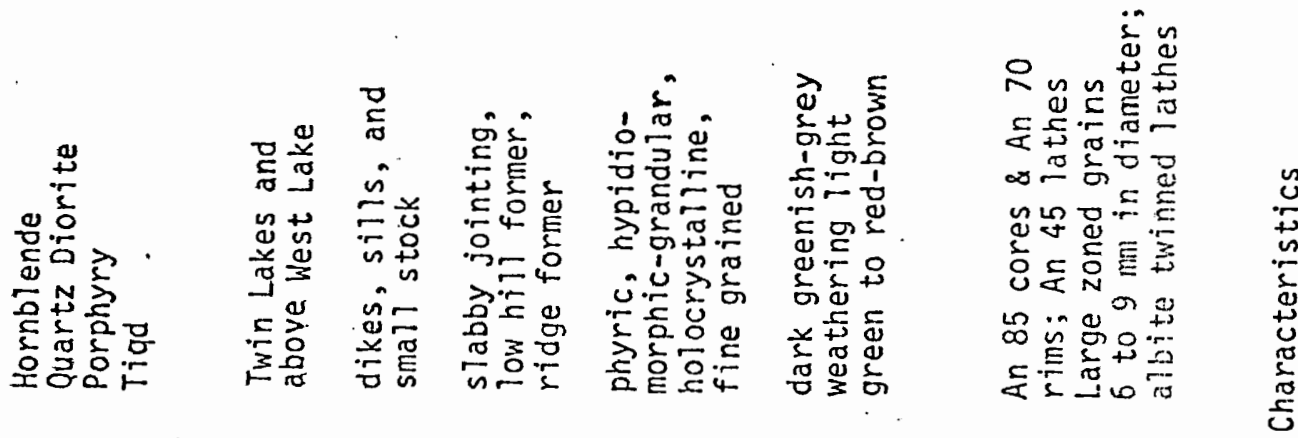

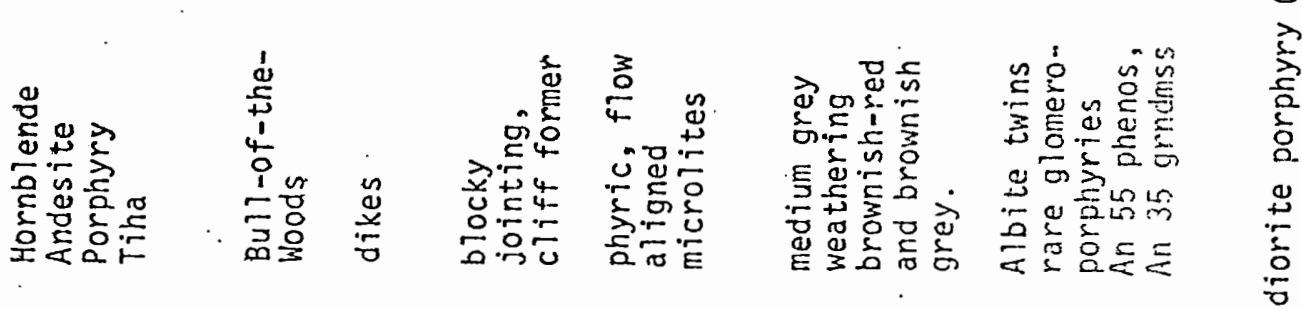

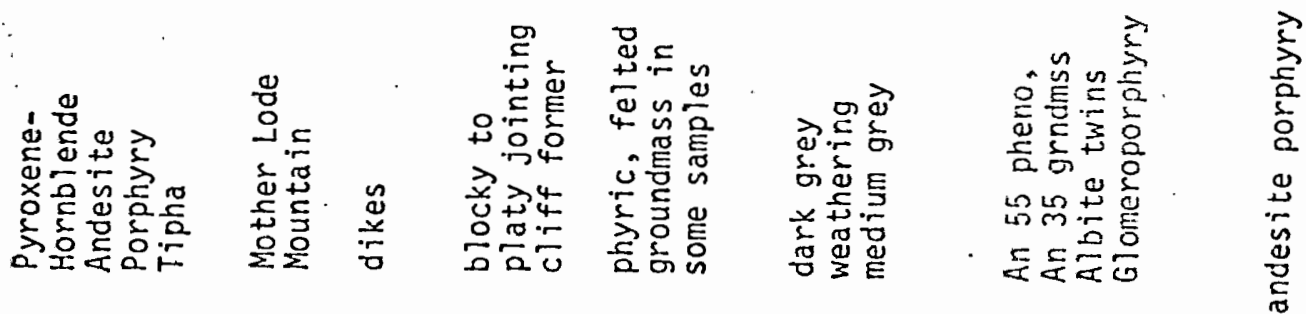

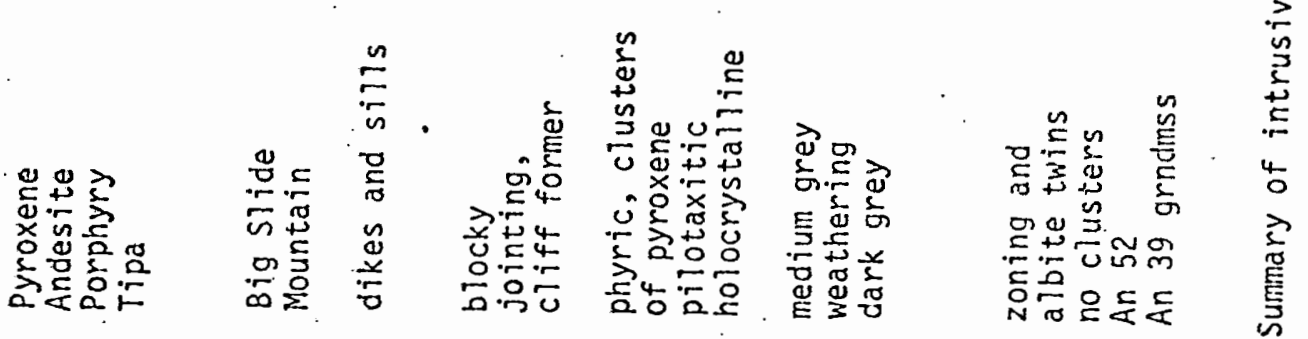
$\underset{\check{C}}{\check{0}}$

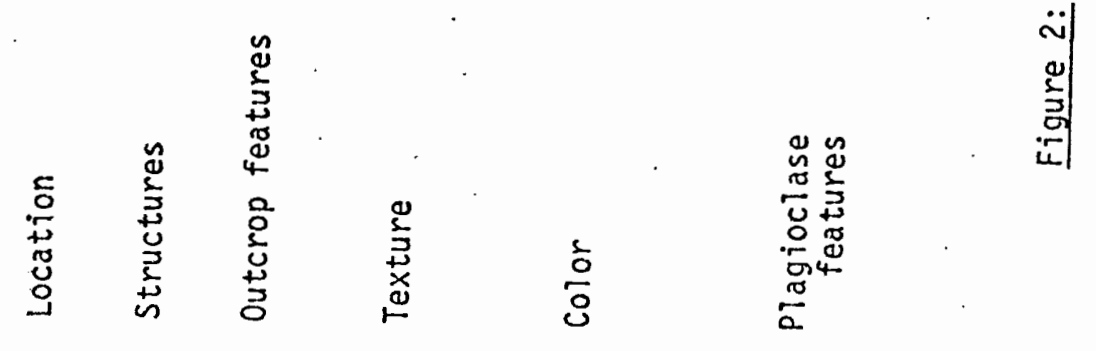



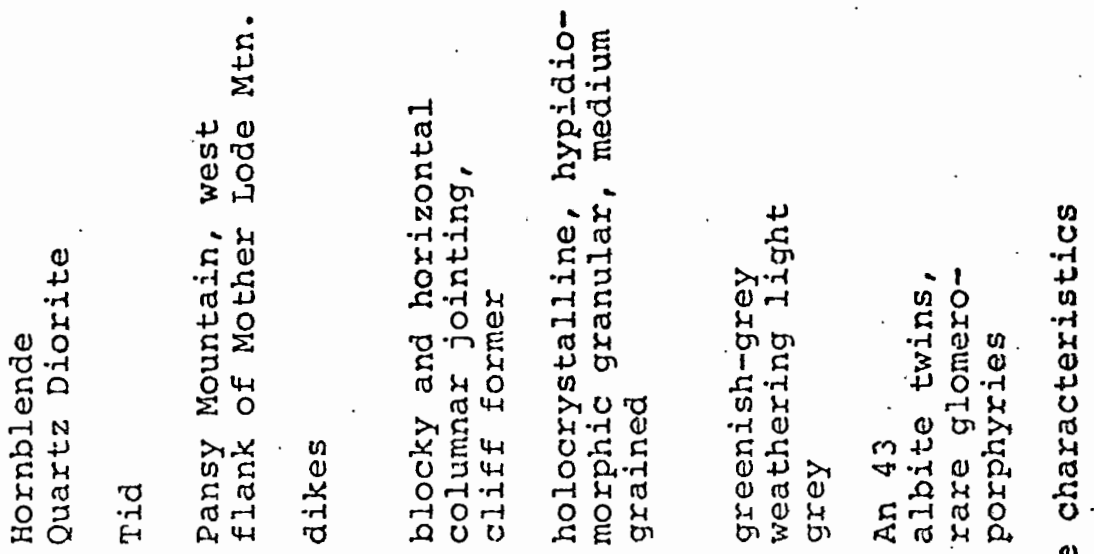

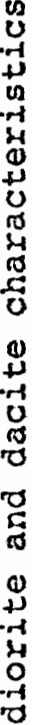

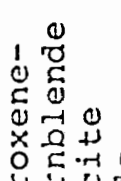

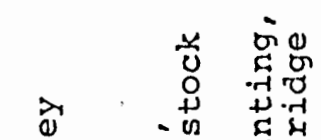

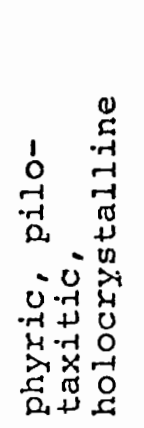

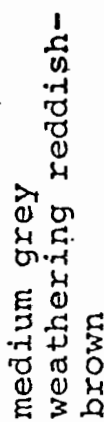

र्या

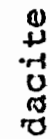

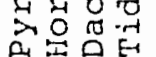

声希 递它出出

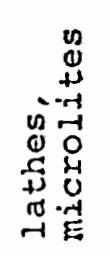

궁ㅇ

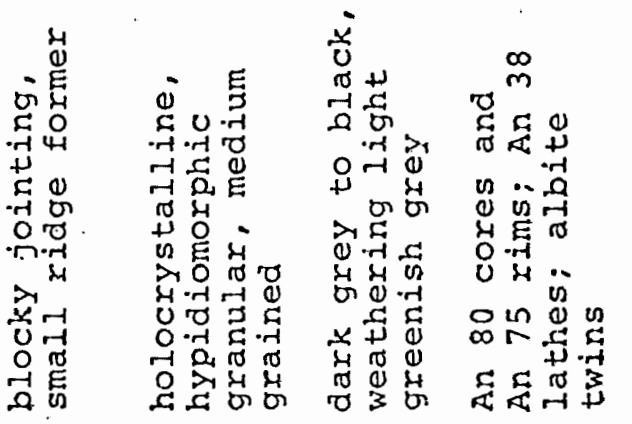

委家

$\stackrel{0}{-10}$

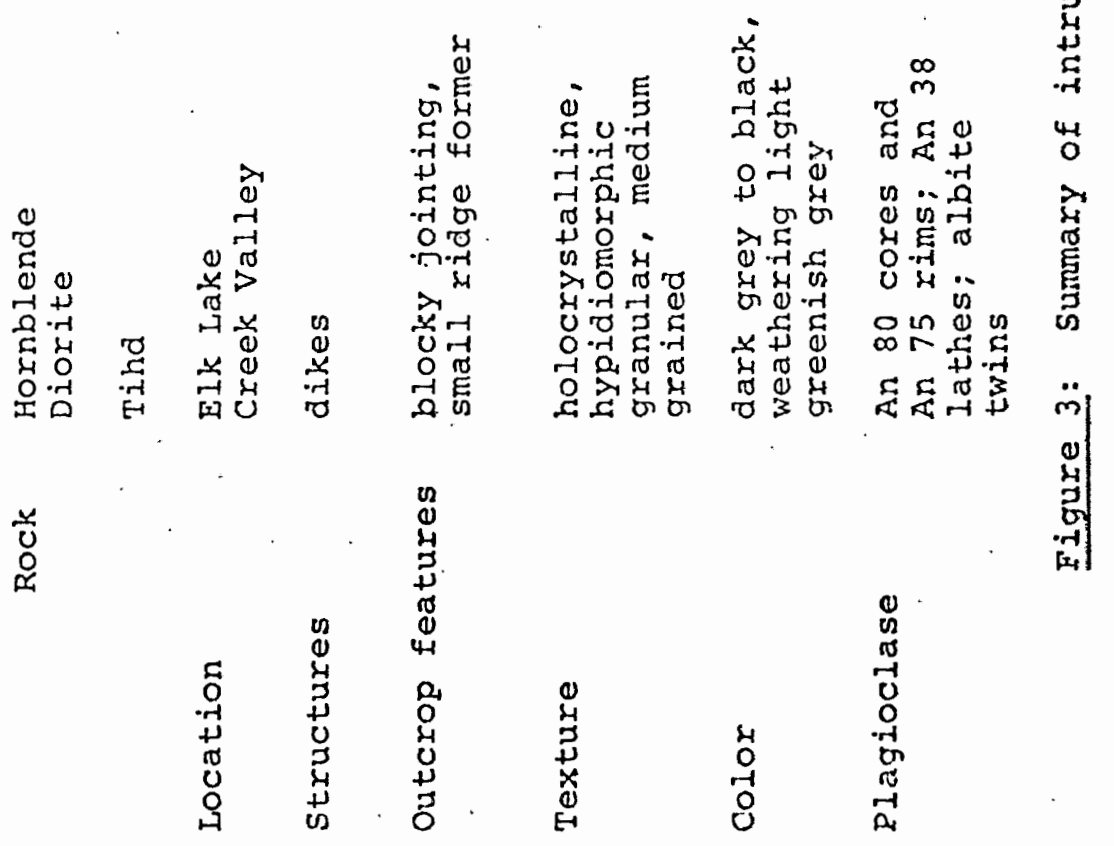




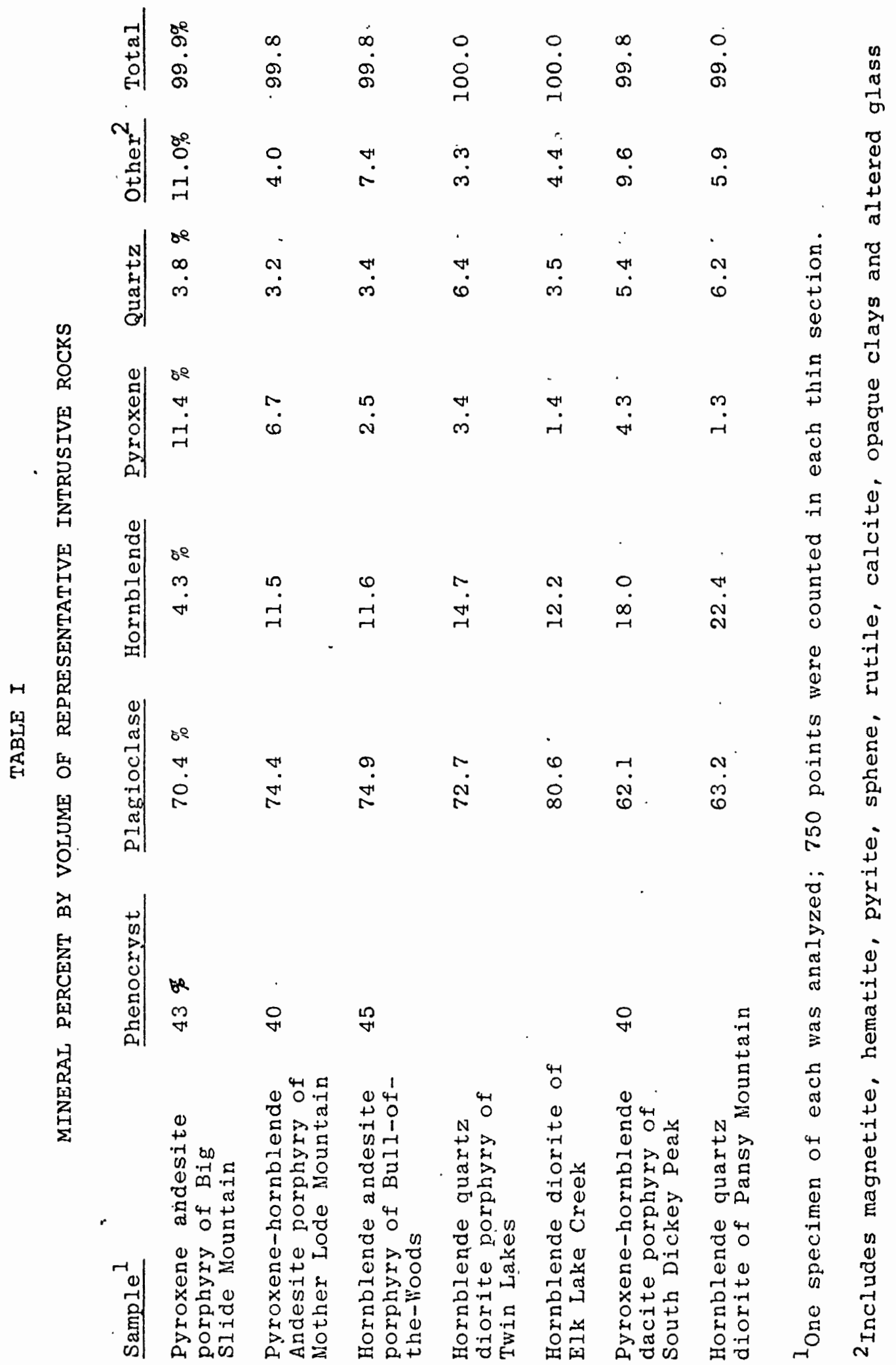


The andesite and dacite groundmass ranges from 62.0 to 74.9 percent of the rock. The size of grains composing the groundmass increases away from the intrusive contact; thus, the andesites commonly grade from an andesite porphyry at the margin of the intrusion to diorite porphyry or diorite in the center of the intrusion. Intrusions also show a greater proportion of glass at the contact than elsewhere. Glomeroporphyritic clusters of plagioclase phenocrysts and hornblende phenocrysts are common while the groundmass microlites are disposed in a hyalopilitic texture.

The diorites are fine to medium grained, have an hypidiomorphic-granular textüre and are holocrystalline. Interstitial grains less that one-half millimeter in diameter compose less than 1 percent of these rocks. The diorites are propylitically altered.

Intrusive andesite can be distinguished from the upper Sardine Formation andesite lava flows by the following: intrusive outcrops show blocky jointing while outcrops of flow show platy jointing; no vesicles are found in intrusive andesites while flow andesites show vesicles; in thin section, intrusive andesite has augite clinopyroxene while andesite lava flow. has hypersthene.

Pyroxene Andesite Porphyry of Big Slide Mountain (Tipa)

Andesite porphyry peppered with pyroxene prisms occurs as sills and dikes on Big Slide Mountain (Plate 1). The sills intrude the tuff of Pansy Basin, and may be distinguished from the interstratified andesite lava flow of the tuff Pansy Basin by the glassy margins of the 
upper and lower contacts of the sill, and by the baking and brecciation of the host rock. The sills and dikes are more coarsely crystalline at their centers than at their margins.

In hand specimen, the rock is medium grey, weathering dark grey. Pyroxene phenocrysts occur as dull, stubby prisms $2 \mathrm{~mm}$ long. Plagioclase lathes are 1 to $3 \mathrm{~mm}$ long.

In thin section of the rock is composed of 43 to 67 percent phenocrysts of clinopyroxene and plagioclase (Table I). Phenocrysts of plagioclase (An 52) are subhedral to euhedral, both zoned and albite twinned. Glomeroporphyritic clusters at plagioclase are absent. Clinopyroxene occurs as euhedral prisms in rare glomeroporphyritic clusters; the $2 \mathrm{~V}$ is 60 degrees and positive, typical of augite. Some pyroxene grains are mantled by green hornblende. The groundmass is composed of flow aligned microlites of plagioclase (An 39) clinopyroxene, and hornblende, and anhedral quartz. Grains of magnetite and hematite are disseminated throughout the rock.

Pyroxene-Hornblende Andesite Porphyry of Mother Lode Mountain (Tipha)

Andesite porphyry dikes, distinguished by phenocrysts of both pyroxene and hornblende, occur in the south half of the study area on Mother Lode Mountain (Plate 1). The dikes are $330 \mathrm{~m}$ to $1500 \mathrm{~m}$ long and 1 to $3 \mathrm{~m}$ wide. The rock is dark grey, weathering medium grey. Plagioclase phenocrysts are squarish and $1 \mathrm{~mm}$ in diameter. Hornblende needles are $2.5 \mathrm{~mm}$ in length, while dull, stubby prisms of pyroxene are 0.5 to $1.0 \mathrm{~mm}$ in length.

Phenocrysts of plagioclase, hornblende, clino- and orthopyroxene compose 40 to 58 percent of the rock. Plagioclase phenocrysts ( $A n$ 55) 
are subhedral to euhedral and occur as glomeroporphyritic clusters $3 \mathrm{~mm}$ in diameter. Green hornblende is euhedral to subhedral and encloses magnetite and hematite. Faint brown.clinopyroxene has a positive $2 \mathrm{~V}$ of 65 degrees and shows no pleochroism, typical of augite. Colorless orthopyroxene phenocrysts have a negative $2 \mathrm{~V}$ of 75 degrees and a positive elongation, typical of hypersthene. The groundmass is composed of plagioclase (An 35), hornblende, pyroxene and anhedral quartz.

Hornblende Andesite Porphyry of Bull-of-the-Woods (Tiha)

Hornblende andesite porphyry occurs as dikes 50 to $1800 \mathrm{~m}$ long and 1 to $8 \mathrm{~m}$ wide throughout the area. It is distinguished by an abundance of lustrous, black hornblende phenocrysts and the absence of pyroxene phenocrysts. The rock is medium grey, weathering brownishgrey. Clear plagioclase phenocrysts are 1 to $2 \mathrm{~mm}$ long, while hornblende phenocrysts are 2 to $3 \mathrm{~mm}$ long. Where exposed, $1 \mathrm{~km}$ north of Bull-of-the-Woods summit, the contact between the intrusive andesite and the host tuff is characterized by glassy margins in the intrusive rock, and a zone of brecciation in the tuff. The host tuff is also contact metamorphosed to the albite-epidote hornfels facies in a zone $5 \mathrm{~m}$ wide.

Phenocrysts of plagioclase and hornblende compose 45 to 60 percent of the rock. Plagioclase occurs as anhedral to subhedral lathes (An 55), 1 to $2 \mathrm{~mm}$ long, and rarely as glomeroporphyritic clusters. Microlites of plagioclase (An 35 ) occur in the groundmass and average $0.4 \mathrm{~mm}$ in length. Green hornblende is euhedral, and encloses rare 
clinopyroxene grains. The groundmass is composed of magnetite, quartz, plagioclase, and hornblende.

Hornblende Quartz Diorite Porphyry of Twin Lakes (Tiqd)

Quartz diorite porphyry, distinguished by large phenocrysts of plagioclase and hornblende, occurs as a stock at Twin Lakes, as a poorly exposed sill along Welcome Creek, and as small dikes above West Welcome Lake. In hand specimen, the rock is dark greenishgrey, weathering light green to brown. Plagioclase phenocrysts are up to $6 \mathrm{~mm}$ in diameter, and are altered to a white clay. Hornblende blades are $3 \mathrm{~mm}$ long, and mantled by green dross. The sill and stock intrude the tuff of Pansy Basin.

The rock is hypidiomorphic-granular, holocrystalline, phyric, and medium grained. Less than 5 percent of the rock occurs as interstitial grains less than one half millimeter in diameter. Plagioclase occurs in two forms: Subhedral to euhedral lathes (An 45), 2 to $3 \mathrm{~mm}$ long; and zoned euhedral phenocrysts from 6 to $9 \mathrm{~mm}$ in diameter with rims (An 70) and cores (An 85). Hornblende is green, subhedral to euhedral, 2 to $3 \mathrm{~mm}$ long and altered to chlorite. Rare clinopyroxene prisms are 1 to $2 \mathrm{~mm}$ long, brown with positive $2 \mathrm{~V}$ of 60 degrees, typical of augite. Anhedral quartz composes 6.4 percent of the rock, and occurs with hematite. The mafic minerals are mantled with chlorite, and plagioclase is riddled with montmorillonite in some slides. All samples of this rock are propylitically altered. 
Hornblende Diorite of Elk Lake Creek (Tihd).

Hornblende diorite dikes trending $\mathrm{N} 45^{\circ} \mathrm{W}$ occur in the valley of Elk Lake Creek (Plate 1). These intrusive rocks are distinguished from other diorites by their abundance of plagioclase, fine grain size, and absence of quartz. The rock is dark grey, weathering light greenish-grey to reddish-brown. Plagioclase grains are visibly twinned in hand specimen, and the hornblende grains are lustrous.

The rock is holocrystalline, hypidimorphic-granular with grains averaging $1.75 \mathrm{~mm}$ diameter. Plagioclase occurs as zoned crystals with rims (An 75) and cores (An 80) and as rare lathes up to $4 \mathrm{~mm}$ long (An 38). Hornblende is green, subhedral and often up to 3 $\mathrm{mm}$ long. Interstitial grains of quartz are anhedral and compose 3.5 percent of the rock. Magnetite occurs in association with hornblende. Clinopyroxene grains are rare and are enclosed in hornblende.

Pyroxene-Hornblende Dacite Porphyry of South Dickey Peak (Tidc)

Dacite porphyry occurs as an irregular stock at South Dickey Peak, and as sills and dikes elsewhere in the study area (Plate 1). Large glomeroporphyritic clusters of plagioclase $1 \mathrm{~cm}$ in diameter distinguish this rock. Hand specimens are medium grey, weathering reddish-brown. Hornblende needles are 2 to $3 \mathrm{~mm}$ long while pyroxene grains are $1 \mathrm{~mm}$ 1ong. A11 exposures of the dacite porphyry intrude the tuff of Pansy Basin. Hornfelsed, slickensided inclusions of the tuff are found in a sill exposed below North Dickey Peak (Plate 1). Phenocrysts of plagioclase, quartz, clinopyroxene, and hornblende compose 40 percent of the rock. The groundmass is pilotaxi- 
tic, and consists of microlites of the same minerals. Plagioclase lathes (An 41) form glomerporphyritic clusters, and plagioclase microlites (An 20) show distinct flow alignment. Hornblende is green, euhedral, and sometimes rims pyroxene grains. Clinopyroxene is brown, and has a positive $2 \mathrm{~V}$ of 60 degrees, typica? of augite. Quartz is anhedral and composes 5.4 percent of the rock. Magnetite and hematite are disseminated throughout the rock; hornblende and pyroxene grains are occasionally altered to chlorite.

Hornblende Quartz Diorite of Pansy Mountain (Tid)

Quartz diorite dikes occur on Pansy Mountain and Mother Lode Mountain. The host rock includes both the tuff of Pansy Basin and the intrusive andesite porphyry of Mother Lode Mountain. The rock is medium grained, equigranular, and has a greater abundance of hornblende than other rocks in the study area. Horizontal columnar jointing and large blocky jointing give outcrops of this rock a stair-step appearance. In hand specimen, it is greenish-grey, weathering light grey.

The rock is hypidiomorphic-granular, medium grained, and holocrystalline. Plagioclase lathes (An 43) are subhedral to euhedral, Aibite twinned, and form rare glomeroporphyritic clusters. Hornblende is green and subhedral. Small grains of augite are enclosed in some hornblende crystals. Clinopyroxene prisms are colorless, average $0.5 \mathrm{~mm}$ in diameter and give indeterminate figures. They are assumed to be augite. Quartz anhedra are 0.4 to $0.7 \mathrm{~mm}$ in diameter. Rutile, magnetite, and hematite occur in association with the hornblende. 
Summary and Discussion

The intrusive rocks of the study area show textural and compositional features suggesting the following conclusions:

(1) the rocks are comagmatic; (2) the rocks crystallized at shallow depths; (3) the fine grained andesites and dacite were emplaced first, and the coarser grained rocks were emplaced later.

Rocks derived from the same parent magma are said to be comagmatic (Jackson, 1970). Several petrographic criteria may be applied to andesites that suggest different andesite/diorite rocks are either comagmatic or not comagmatic. These criteria, however, are not conclusive in themselves, and must be supported by chemical evidence (Hyndman, 1972). Rocks which display "a common chemical or mineralogical similarities . - are assumed to be comagmatic" (Jackson, 1970). Such similarities include mineral composition, plagioclase composition and textural characteristics.

Comagmatism of these rocks is suggested by the narrow range of textural and compositional variation, and by specific features of the component minerals. The variety of names applied to these rocks is a result of the nomenclature used, and does not reflect largescale variations in composition. Quartz is used to distinguish dacites and andesites, diorites and quartz diorites; its actual variation in the suite of rocks is from 2.8 to 6.4 percent. The distinction between andesite porphyry and diorite porphyry is based on the percentage of groundmass grains equal to or greater than onehalf millimeter in diameter. Nearly all of the intrusive bodies with andesite porphyry composition possess an "inner core" of rock where 
the texture is actually diorite porphyry. Hornblende is the most abundant mafic mineral in these rocks, and it varies inversely with pyroxene, specifically augite. Plagioclase is commonly found in glomeroporphyritic clusters. These variations in hornblende and plagioclase are small enough to suggest the parent melt of these rocks shared a common cooling history, and possibly a common elemental abundance. This point will be explored in CHAPTER IV.

The fine grained nature of many of these rocks suggests they cooled quickly. Phenocrysts found in the chilled margins of these rocks could not have crystallized in situ, but must have formed at depth before the body of magma was mobilized. The small $5 \mathrm{~m}$ zones of contact metamorphism found at the contacts of the intrusions suggest that they were emplaced at shallow depth. The diorites have zoned and twinned plagioclase grains. This suggests a change in the magma body as the plagioclase cooled. Such a change may have been due to a loss of volatiles, which occurs as the magma nears the surface (Carmichael, et a1, 1974).

Diorites intrude the andesite porphyry of Mother Lode Mountain and the andesite porphyry of Bull-of-the-Woods. These relations observed in the field demonstrate that these fine grained rocks intruded the host tuff first, and the diorites were emplaced later. Large sills and stocks of diorite found at lower elevations in the area also suggest that the diorite followed the andesite into the area. 
CHAPTER IV

\section{MAJOR AND TRACE ELEMENT GEOCHEMISTRY}

\section{INTRODUCTION}

Discussions of magma genesis and differentiation center on variations in mineralogy and major element oxide concentrations (Carmichael et a1, 1974; Ringwood, 1975). Recent work in geochemistry has revealed that rock suites with very similar mineral and major element oxide concentrations can have very dissimilar trace element concentrations. The differences in trace element concentration must also be accounted for in terms of magma genesis. In this study, major and trace element analysis has been conducted to determine if the present suite of rocks is comagmatic, and if so, to determine lines of chemical differentiation.

On the basis of mineralogy and major element oxide abundances, andesites have been labeled 'intermediate' in composition between basalts and granites. Andesite magma could presumably be generated by the proper mixing of a basaltic and granitic magma. Taylor and White (1966) have shown that the trace element abundances of andesites are too low to be obtained by such mixing (Figure 4).

Andesites display a characteristically limited variability in trace element abundances (Gunn, 1974). This range is further subject to 1 imitations within distinctive volcanic provinces, and definite trends of variation appear within each province. Differentiation 


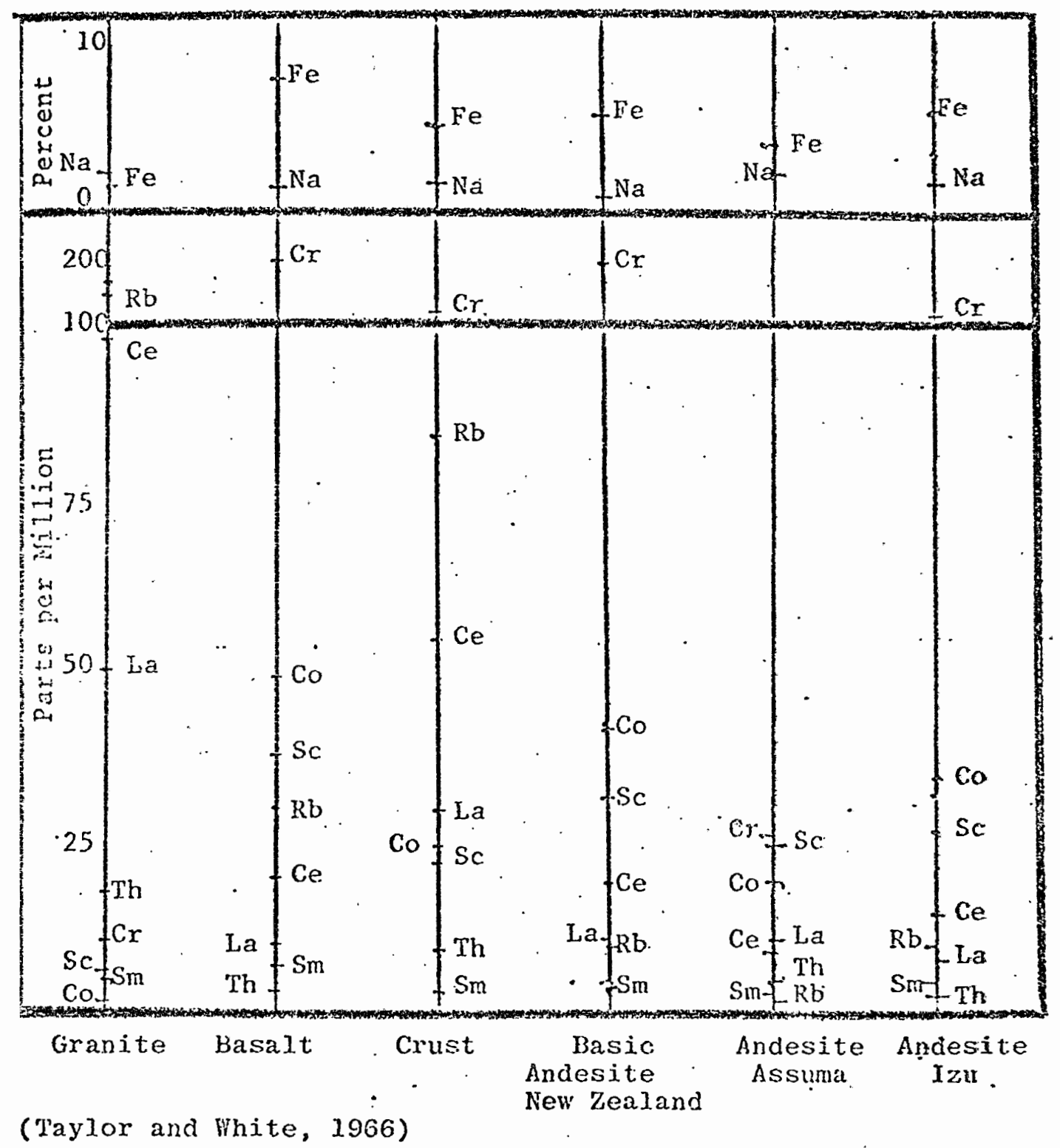

Figure 4: Major and trace element abundances in rocks 
effects, however, are minor in andesites, "due to the common coprecipitation of several crystal phases" (ibid). Where differentiation occurs, $\mathrm{Na}, \mathrm{La}, \mathrm{Rb}$, and $\mathrm{Ba}$ will increase in concentration, while $\mathrm{Fe}, \mathrm{Co}, \mathrm{Sc}$, and $\mathrm{Cr}$ will decrease (Goldrich et al, 1975).

The effects of minor differentiation can be masked by alteration. Concentrations of $\mathrm{Na}, \mathrm{Fe}$, and $\mathrm{Cr}$ can increase through alteration, while concentrations of $\mathrm{Rb}, \mathrm{Ba}$, and Th can decrease (Gunn, 1974). Certain elements are immobile during alteration and metamorphism, and therefore, can be used to identify different magma series and their differentiation products. Ce and Sc are among these elements (Winchester and Floyd, 1977).

Rocks derived from the same parent magma are comagmatic. If their mineral phases are similar, then different comagmatic rocks will have very similar concentrations of trace elements. Moreover, the ratios of elements which occupy the same crystal lattice sites will be the same in the different rocks. For example, Fe and Co have the same charge and approximately the same ionic radius: they occupy the crystal sites and the ratio $\mathrm{Fe} / \mathrm{Ce}$ will be the same value in comagmatic rocks. Isotope ratios, such as $5 r^{87} / \mathrm{sr}^{86}$, will also be the same for different rocks with a common parent magma (Carmichael et al, 1974).

Few authors report specific criteria that may be used to identify comagmatic rocks through the use of trace element data. Most comagmatism arguments are framed in terms of mineralogy or major element oxides, However, Frey et al (1978) state light rare earth element abundances ( $\mathrm{La}, \mathrm{Ce}, \mathrm{Sm}$ ) that vary by less than a factor of two are 
consistent with a comagmatic model. Goldrich et a1 (1975) and Smith (1978) use trace and major element concentrations to identify comagmatic suites of rocks. The ranges of variation for individual elements within these suites are presented in Tables II to VIII.

Twenty seven samples were analyzed through neutron activation analys is for $\mathrm{Fe}, \mathrm{Na}, \mathrm{La}, \mathrm{Ce}, \mathrm{Eu}, \mathrm{Sm}, \mathrm{Lu}, \mathrm{Ba}, \mathrm{Th}, \mathrm{Cr}, \mathrm{Hf}, \mathrm{Rb}, \mathrm{Sc}$, and Co. Each intrusive lithology was sampled at least once.

\section{INTRUSIVE LITHOLOGY GEOCHEMISTRY}

Each identified intrusive lithology (CHAPTER III) was sampled at least once (Tables II to VIII). The following discussion follows the order in CHAPTER III. Sample locations are shown on Figure 8 and described in the Appendix.

The pyroxene andesite porphyry of Big Slide Mountain samples (Table II) appear to be comagmatic with each other. Immobile Sc and Ce are very close in concentration to the average value for the set. Light rare earth values are within one standard deviation of each other for each sample, and are within the factor of 2 criteria of Frey et a] (1978). There is no strong evidence of differentiation within the set.

The pyroxene-hornblende andesite porphyry of Mother Lode Mountain samples (Table III) also appear to be comagmatic with each other: both $\mathrm{Sc}$ and $\mathrm{Ce}$ occur in a narrow range of concentrations, while the light rare earth elements are within a factor of 2 for each element. Again, there is no strong evidence for differentiation within the samples of this set. 


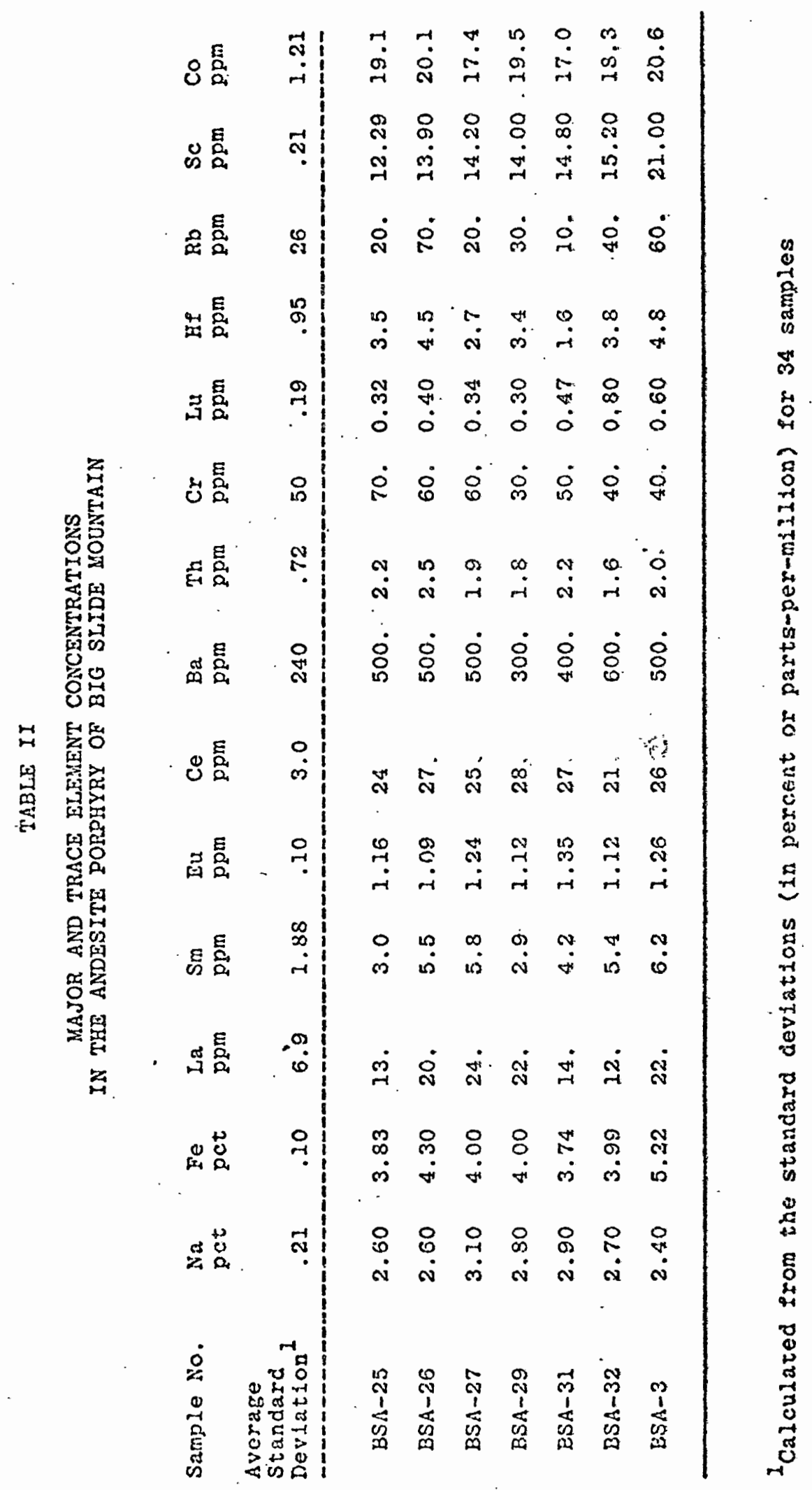




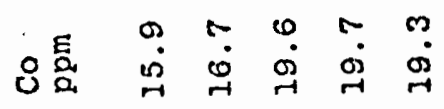

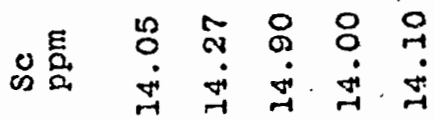

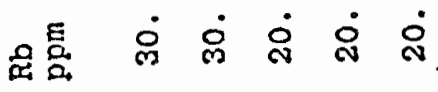

密 出

录会

范

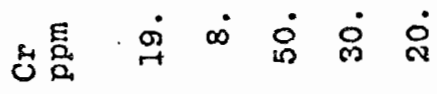

筧 80

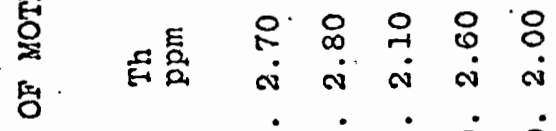

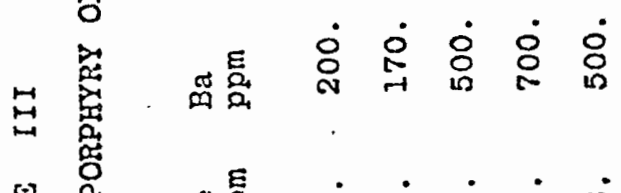

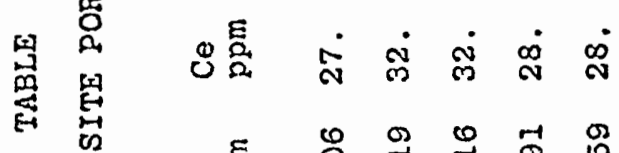

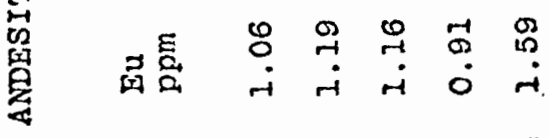

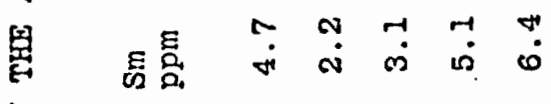

学

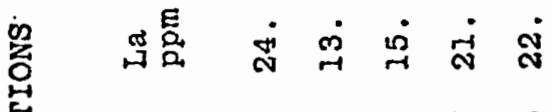

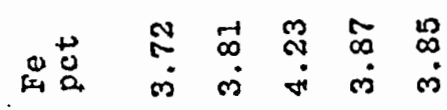

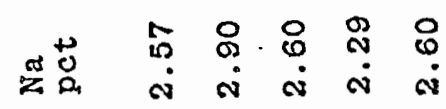

总 
욤

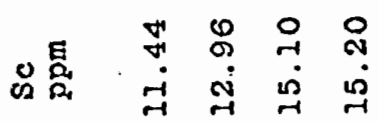

虽

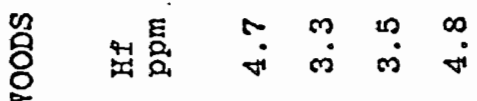

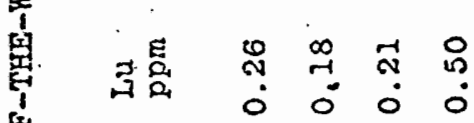

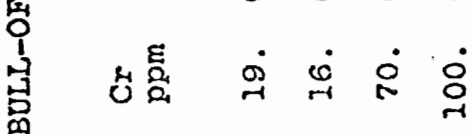

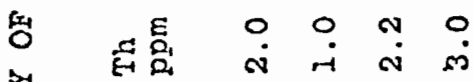

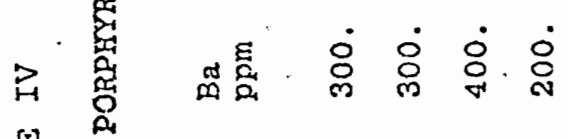

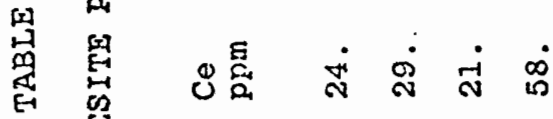

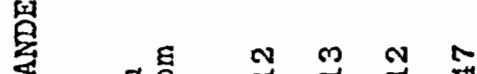

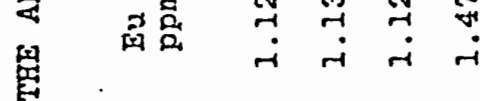

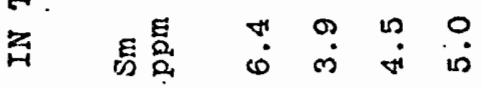

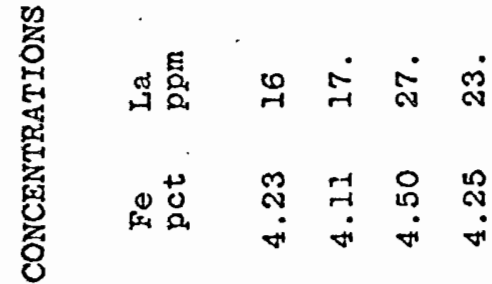

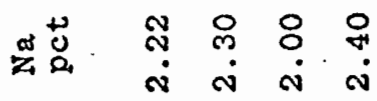

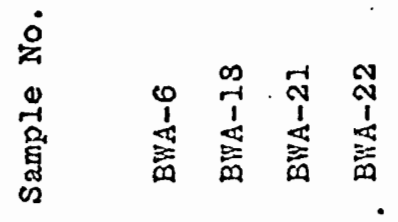




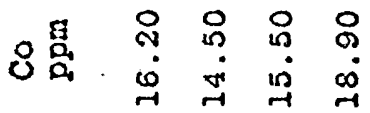

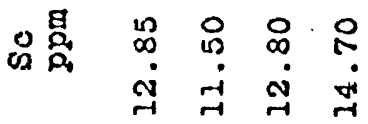

$$
\begin{aligned}
& \text { 星是宫宗定宫 } \\
& \text { 崮星 } \\
& \text { 表最 }
\end{aligned}
$$

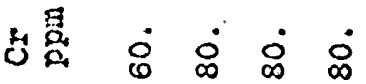

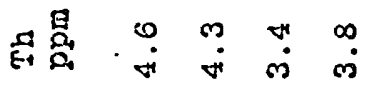

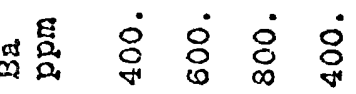

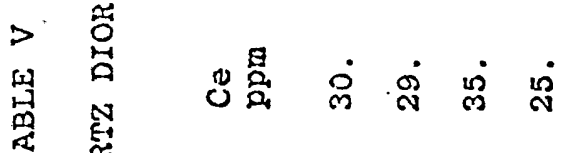

$$
\begin{aligned}
& \text { Es }
\end{aligned}
$$

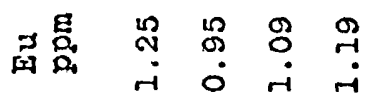

$$
\begin{aligned}
& \text { 䎕 昆暴 }
\end{aligned}
$$

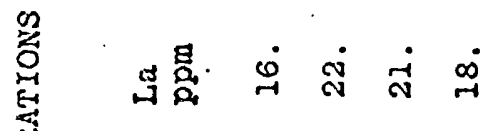

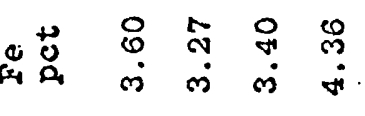

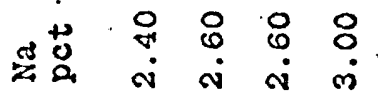

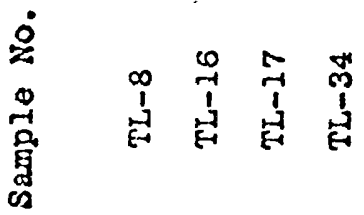




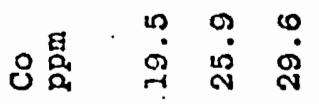

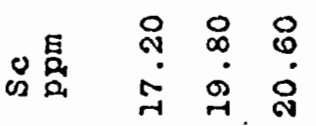

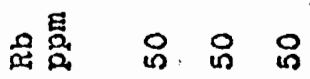

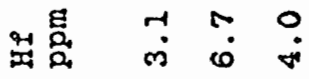

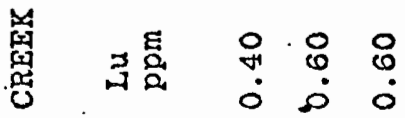

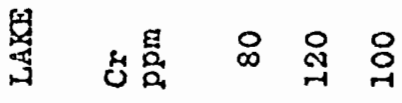

舁 $\quad$ 目

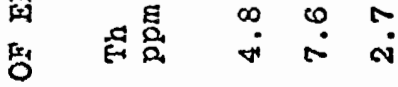

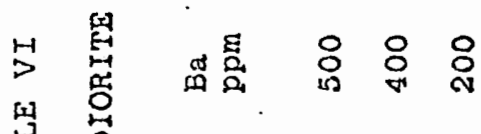

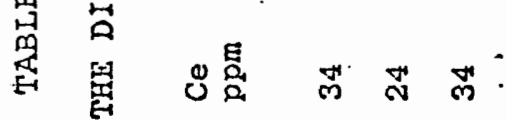

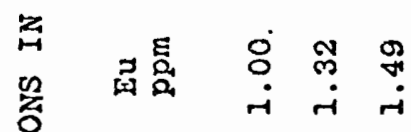

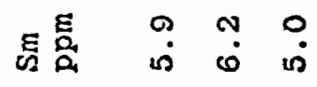

ง

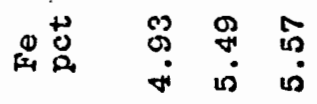

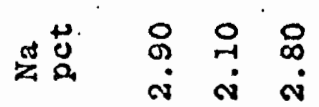

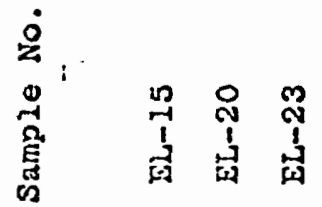




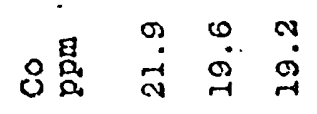

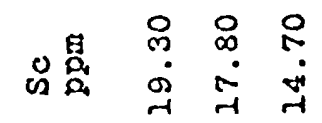

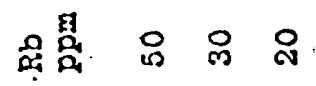

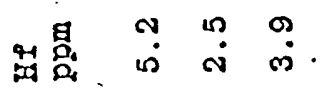

$$
\begin{aligned}
& \text { A } \\
& \text { 当䅪 }
\end{aligned}
$$

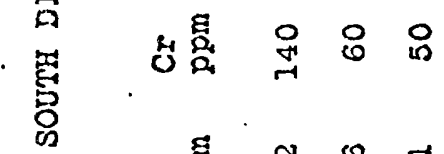

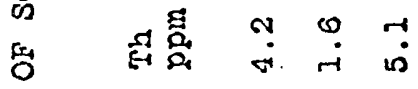

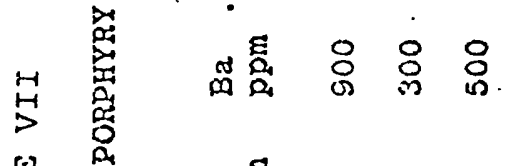

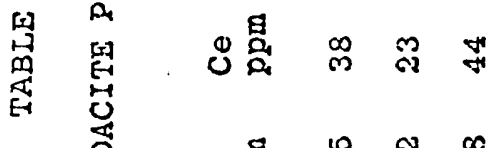

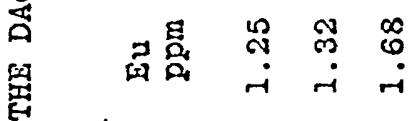

$$
\begin{aligned}
& \text { 杂 昆思 }
\end{aligned}
$$

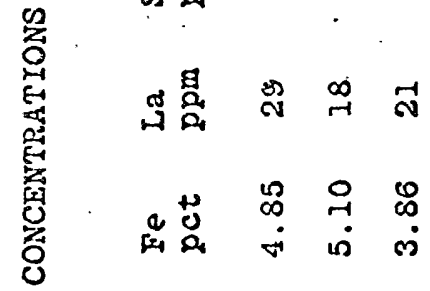

$$
\begin{aligned}
& \text { 雚莒 }
\end{aligned}
$$

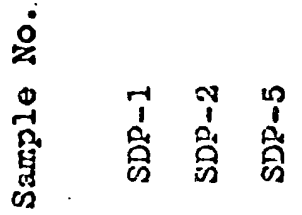




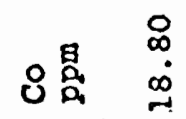

$$
\begin{aligned}
& \text { 星 品 } \\
& \text { 象爵 }
\end{aligned}
$$

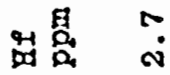

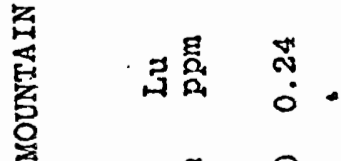

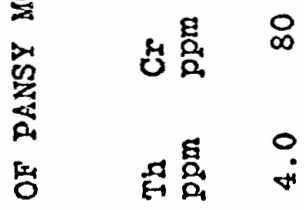

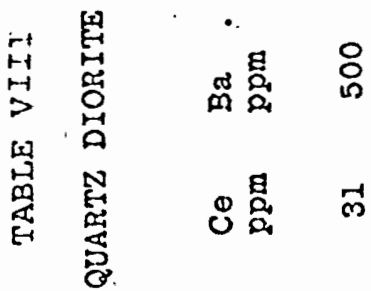

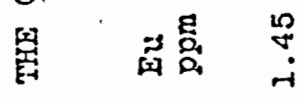

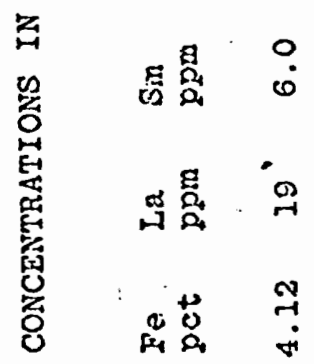

$$
\begin{aligned}
& \text { 赵莒 } \\
& \frac{0}{2} \\
& \text { a }
\end{aligned}
$$


The hornblende andesite porphyry of Bul1-of-the-Woods samples (Table IV) appear to be comagmatic with each other. Sc shows a narrow range of values when compared to the data of Taylor (Figures 4 and 5) and Ce shows a narrow range of values, except for sample 22 . The light rare earths fall within a factor of 2 , if sample 22 is excluded. Sample 22 shows anomalous values for $\mathrm{Eu}, \mathrm{Ce}$, and $\mathrm{Lu}$. These elements are not affected by alteration or differentiation of a minor degree. Therefore, these values may reflect the effects of contamination of the sample, instrumental error or some other action not detected in the. the study. The concentrations of $\mathrm{Fe}, \mathrm{Cr}, \mathrm{Sc}$, and $\mathrm{Co}$ suggest mild differentiation in the order sample 21 , sample 6 , sample 18.

The hornblende quartz diorite of Twin Lakes samples (Table V) is a comagmatic set: $\mathrm{Sc}$ and $\mathrm{Ce}$ show small variations between samples, and the light rare earths show concentrations within a factor of 2 . Al1 samples are propylitically altered, and sample 34 is the most altered. This alteration probably accounts for the high $\mathrm{Na}$ and $\mathrm{Fe}$ values in sample 34 . There may be some mild differentiation among the samples in the order sample 34, sample 8, samples 16 and 17 , however the trends are not consistent, and probably masked by alteration. The hornblende diorite of Elk take Creek samples (Table VI) are comagmatic: Ce and Sc show a narrow range of values, as do the light rare earths. Sample 15 is slightly differentiated from samples 20 and 23: $\mathrm{N} \dot{\alpha}, \mathrm{La}$, and $\mathrm{Ba}$ are enriched while $\mathrm{Fe}, \mathrm{Sc}, \mathrm{Cr}$, and $\mathrm{Co}$ are depleted. The higher concentrations in sample 23 of $\mathrm{Na}$ and $\mathrm{Fe}$, and the lower concentrations of Th suggest that sample 23 was more altered than the other samples: All samples in this lithology are propylitically 


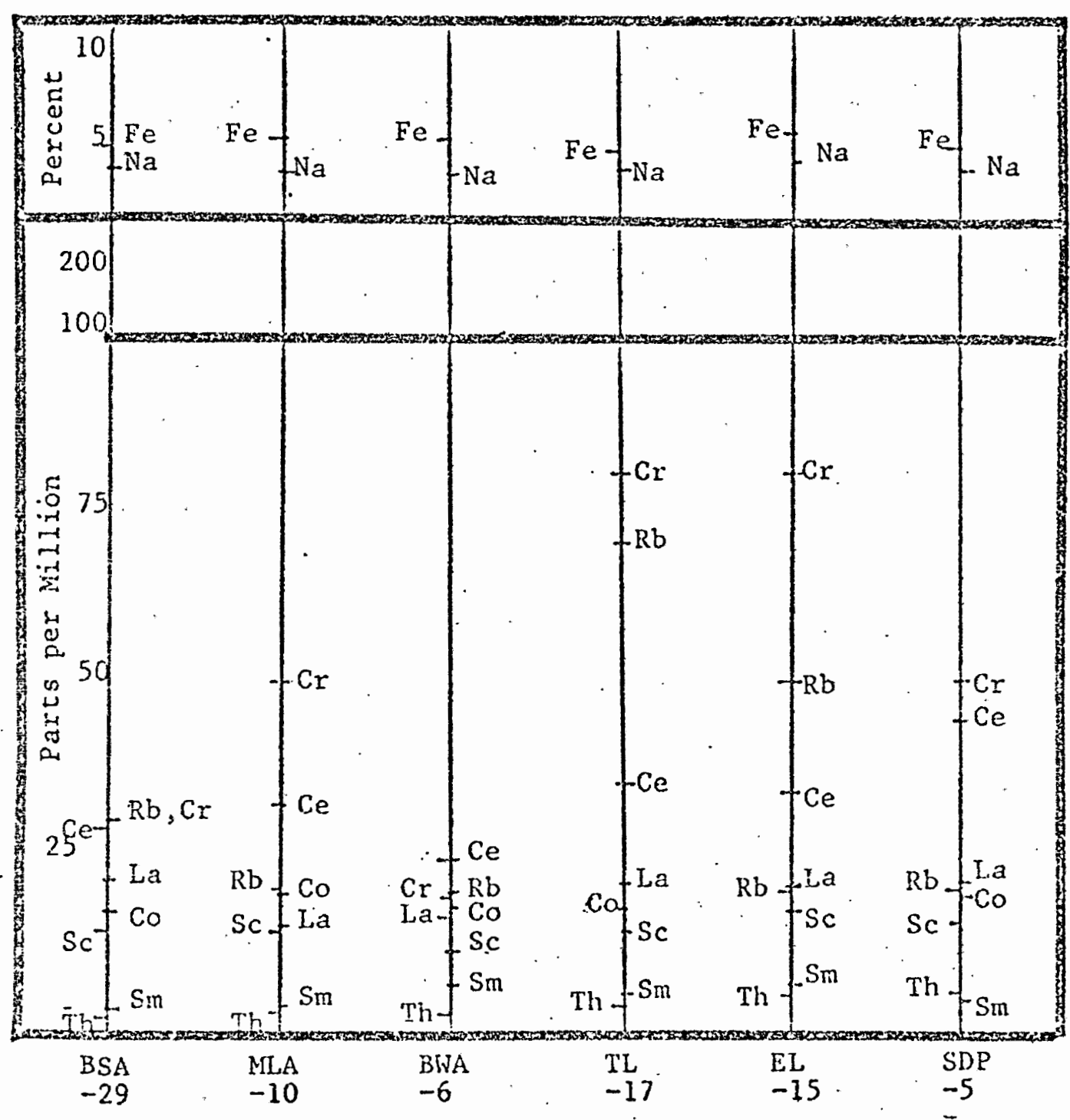

Figure 5: Major and trace element abundances in Bull-of-the-Woods intrusive rocks 
altered, but the degree of alteration is not distinguishable in thin section.

The dacite porphyry of South Dickey Peak samples (Table VII) are comagmatic: Sc values are close to each other, but the Ce values, while falling within a factor of 2 are not as close to each other as in other lithologies. The other light rare earth elements also fall within a factor of 2 in concentration. There is no consistent trend in these samples that supports differentiation. All three samples are altered propylitically which may account for the differences in values of $\mathrm{Fe}, \mathrm{Na}, \mathrm{La}, \mathrm{Ba}, \mathrm{Th}$, and $\mathrm{Rb}$.

Onty one sample was analyzed from the hornblende quartz diorite of Pansy Mountain (Table VIII). Except for the low Na concentration, its element concentrations fall within the range of values for the total set of analyzed samples, but not within the range of any other 1 ithology.

\section{COMPARATIVE PETROLOGY}

The range of element concentrations in this study is close to that found by Taylor and White (1966) for andesites in other areas (Figure 5). Some variations in element abundance characterize these andesites and diorites with respect to those reported elsewhere: These rocks are lower in $\mathrm{Fe}, \mathrm{Na}, \mathrm{Cr}, \mathrm{Sc}$, and $\mathrm{Co}$; and they are higher in $\mathrm{Ba}$, Th, Sm, Eu, and $\mathrm{Hf}$. This difference in abundances may reflect either a lack in control of $\mathrm{SiO}_{2}$ content in this study (Taylor's andesites were normalized at $60 \% \mathrm{SiO}_{2}$ ), or they may be the 'signature' 
of this province or this part of the province. Insufficient data is available for Cascades rocks to determine if there is a significant difference between these values and those for similar rocks found in either the Western Cascades or High Cascades (McBirney, 1968).

The entire set of samples appears to be comagmatic. The light rare earth elements vary within a factor of 2 , the criteria established by Frey et al (1978) for comagmatism. Sc also shows a narrow range of values, especially if the high concentration, in sample 22 is omitted.

Cobait and ferrous iron have similar ionic radii, and cobalt shares a +2 charge with the ferrous iron. For these reasons, cobalt substitutes readily in crystal lattice sites normally occupjed by $\mathrm{Fe}^{+2}$. A strong case for comagmatism can be made for these samples on the basis of the Fe/Co ratio (Figure 6). Nearly all the samples fall within the instrumental error of the ratio indicated by the left sloping line. The samples falling farthest from the line are altered, which may account for their deviation. Differentiation can also be observed in this figure: the most differentiated are $\mathrm{Fe}$ and $\mathrm{Co}$ depleted and fall on the left side of the figure, while the least differentiated are $\mathrm{Fe}$ and $\mathrm{Co}$ enriched and fall on the right side of the figure. The quartz diorite samples of Twin Lakes appear to be the most differentiated, while the diorite of Elk Lake Creek appear to be the least differentiated. The other lithologies appear to be equally differentiated, and intermediate between these two groups.

The ratio of Sc and $\mathrm{Fe}$ also shows covariation similar to that of $\mathrm{Co}$ and $\mathrm{Fe}$ (Figure 7), though the trend is less well defined due 


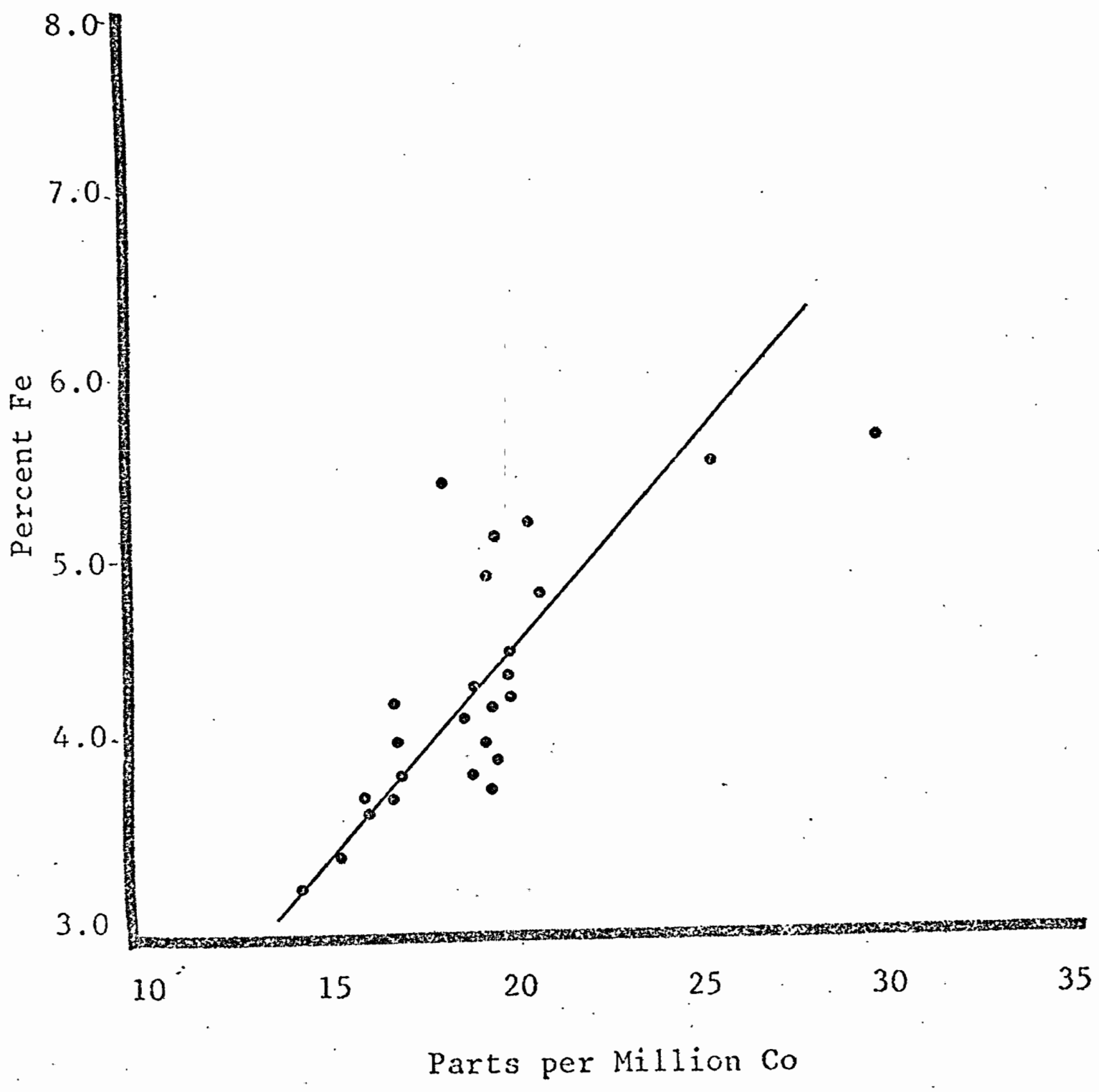

Figure 6: Covariation of Iron and Cobalt in Bull-of-the-Woods intrusive rocks 


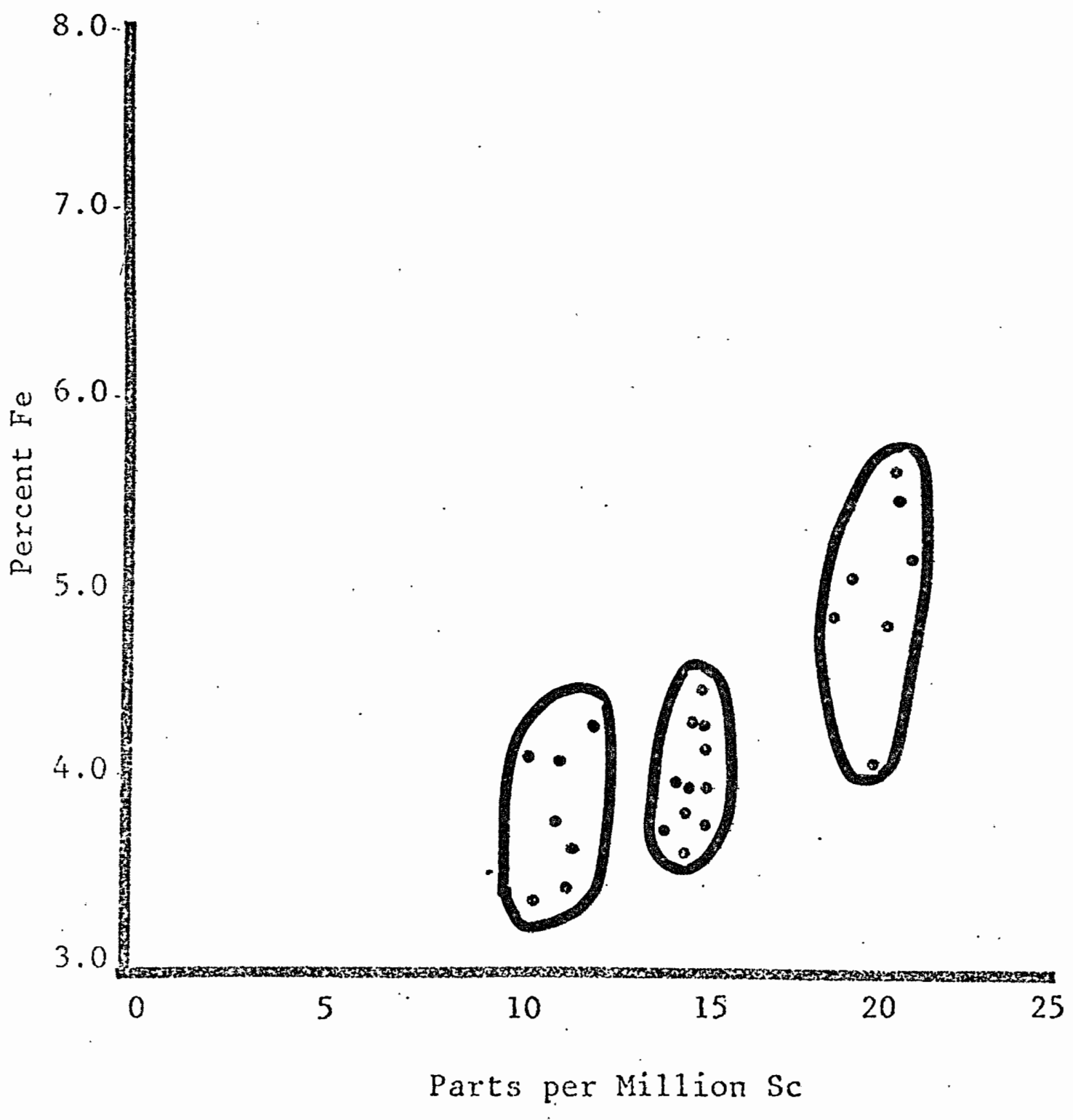

Figure 7: Covariation of Iron and Scandium in BulI-of-the-Woods intrusive rocks 
to a greater difference in ionic radii between Sc and Fe. Again, the diorite of Elk Lake Creek appears less differentiated than the other samples, while the quartz diorite of Twin Lakes appears more differentiated.

The concentrations of Sc in these samples fall into three groups: a low group of less than $14 \mathrm{ppm}$, a middle group of 14 to $15 \mathrm{ppm}$, and a high group with greater than $15 \mathrm{ppm}$. The geographic distribution of these groups (Figure 8 ), shows a pattern of low concentrations in the middle of the study area, and of high concentrations on the outer margins of the area. It suggests these intrusions were derived from a common parental magna which underwent mild gravity differentiation. Before the differentiation was completed, the magma chamber was tapped, yielding first the light fraction, then the medium, possibly parental fraction, and finally the heavier fraction.

\section{SUMMARY}

The samples analyzed in this study are comagmatic. This relation is shown by the limited variation in light rare earth element concentrations, by the nearly constant ratios of $\mathrm{Fe} / \mathrm{Co}$ and $\mathrm{Fe} / \mathrm{Sc}$, and by the narrow range of variation of other elements when compared to the variation in comagmatic suites identified elsewhere. Differentiation is inherently limited in andesites as compared with other rock suites (Gunn, 1974). There is a minor differentiation with in the andesite porphyry of Bull-of-the-Woods samples, the quartz diorite of Twin Lakes samples, and the diorite of Elk Lake Creek samples. The diorite of Elk Lake Creek is the least differentiated 


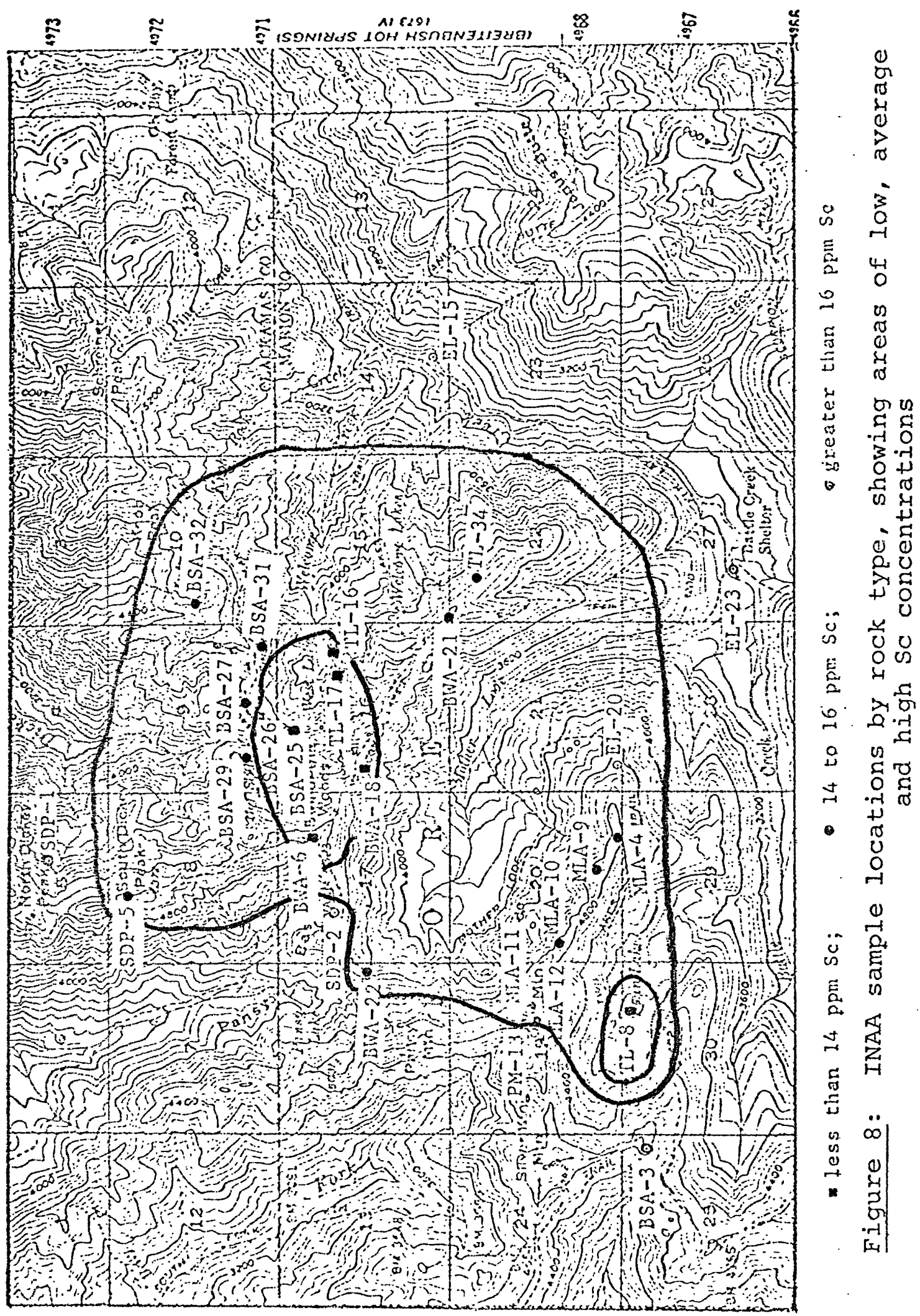


suite in the set, and the quartz diorite of Twin Lakes is the most differentiated suite. Most differences in concentrations of $\mathrm{Fe}, \mathrm{Na}$, $\mathrm{Cr}, \mathrm{Rb}, \mathrm{Ba}$, and Th not accounted for by differentiation appear to be due to alteration. The geographic zoning of Sc concentrations suggest the parental magma underwent gravity differentiation. 


\section{CHAPTER $V$}

\section{STRUCTURAL GEOLOGY.}

\section{INTRODUCTION}

The Sardine formation is mildly deformed by folding in the study area, and does not appear to be faulted. Unconformities within the Sardine formation consist of canyons cut into the lower tuff member into which andesite lava flowed. The Sardine Formation is host to a series of intrusions in the form of dikes, sills and small stocks. The host rock is brecciated, deformed, and contact metamorphosed in a narrow zone around the intrusions.

\section{FOLDING}

Stratified units in the study area show very gentle dips. Attitudes in Pansy Basin and on Big STide Mountain dip 5 to 10 degrees west, while attitudes on Knob Peak and Schreiner Peak dip 5 degrees east. An anticlinal axis may trend north or northeast through the east side of the area, but the lack of exposed bedding in the south east portion of the area prevents definition of a fold axis. No small scale folding was observed in the area. Attitudes taken adjacent to intrusions dip 20 to 35 degrees away from the intrusions. This deformation of host rock resulted from the intrusive event, and not from an episode of folding. 


\section{FAULTING}

No faulting has been revealed in the study area. The absence of marker beds within the tuff of Pansy Basin, and the extensive cover of Quaternary units throughout the area may have prevented the discovery of existing faults. Cataclastic zones in the study area are found only adjacent to intrusions, and therefore cannot be identified with an episode of faulting.

\section{INTRUSIONS}

Intrusions are exposed on the prominent ridges of the area and in valleys along streams. The dikes show three trends: $N$. $45^{\circ} \mathrm{E}$., N. $10^{\circ} \mathrm{E}$. to N. $10^{\circ} \mathrm{W}$, and N. $45^{\circ} \mathrm{W}$. to N. $60^{\circ} \mathrm{W}$.. The andesite porphyries of Mother Lode Mountain, Bull-of-the-Woods, and Big S1ide Mountain trend N. $45^{\circ}$ E. Both Mother Lode Mountain and the Bull-of-the-Woods units are intruded by diorites trending N. $60^{\circ} \mathrm{W}$. These diorites do not occur as dikes trending N. 45 E. While the Bull-of-the-Woods andesite porphyry, the South Dickey Peak dacite porphyry, and the Twin Lakes quartz diorite porphyry trend both north and northwest, the Pansy Mountain and Elk Lake Creek units only trend northwest.

These trends in dike orientation suggest a rotation in regional stress during the period of dike emplacement. Such a rotation would also result in the deformation of the host rock through either folding or fautting, and the deformation in the earlier dikes. These effects are not seen in the study area, and thus the cause of the 
changing orientation of dikes remains unknown.

The dikes in the study area have vertical contacts, and thus they were emplaced after the episode of folding in the host rock.

The quartz diorite of Twin Lakes occurs as a stock at Twin Lakes, and as a sill in Welcome Lake Creek, and on Big S1ide Mountain. Cross-cutting relationships with the andesite porphyry of Bul1-of-theWoods show the diorite was emplaced after the andesite.

Contacts between the host rock and the intrusive rock are characterized by a chill margin within the intrusive rock, by brecciation, contact metamorphism, and local deformation of the host rock. No xenoliths of host rock are found in the intrusions, and while the contacts are sharp and not gradational, the host rock is bowed upward at the intrusive contact. These observations place certain constraints on the mechanism of intrusion. Stoping of the magma is ruled out by the absence of xenoliths of host rock. The magma may have opened fjssures for itself by forcefur injection or it may have followed pre-existing fissures in the host rock. The presence of such fissures, represented by gauge, faults, or joints, has not been observed except at the contact of one intrusion. The deformation and brecciation of the host rock suggest room may have made for the in-... trusion by dilatency of the host rock. The cause and control of this dilatency is not clear from the limited exposure of contacts in the area; the diverse trends and distribution of the intrusions argue : against dilatancy. Given the limited exposure of contacts, it appears likely that the intrusions were emplaced by forceful injection. , 
BATHOLITH

Airphoto studies of the Western Cascades in northern Oregon conducted by the U. S. Forest Service have found northwest trending structures in the region surrounding the study area. However, these structures do not appear within the study area (C. Manning, oral communication). This observation suggests the presence of a large body at depth beneath the area that protects. it from deformation by regional stress. The presence of such a body at shallow depth beneath the study area would result in extensive thermal metamorphism and deformation of the host rock. The degree of contact metamorphism and propylitic alteration does not indicate a large source of heat or volatiles near the surface. The limited exposures of beds of host rock do suggest a very gentle arching through the area that may be the result of intrusion of a large body at depth. While a large body of plutonic rock does appear to underlie the area, the extent of its deformation of the host rock suggests it is not greater than $100 \mathrm{sq} \mathrm{km}$, and therefore it must be termed a stock. The limited effects of thermal metamorphism in the area suggest the pluton is at a depth greater than 1000 $m$, the range of contact metamorphism commonly found near the Sierra Nevada batholith (Hyndman, 1972). 


\section{CHAPTER VI}

CONCLUSION

\section{PETROGRAPHY}

The intrusive rocks show a narrow range of petrographic variation consisting of andesite porphyry, diorite porphyry, dacite porphyry, quartz diorite porphyry, diorite, and quartz diorite. Plagioclase composes 62 to 80 percent of these rocks, quartz ranges from 2.8 to 6.4 percent: Hornblende is the most abundant mafic mineral, ranging up to 22 percent of the rock. Clinopyroxene is less abundant, composing no more than 12 percent of the rock, and generally ranging between 2 and 5 percent. Glomeroporphyritic clusters of plagioclase are common in these rocks. Groundmass plagioclase ranges from An 35 to An 45. The diorite and quartz diorite are hypidiomorphic-granular; fine medium grained, and holocrystalline. All the intrusions of andesite porphyry and diorite porphyry are more coarsely crystalline in their centers than on their margins. The ranges of texture and composition in these rocks suggest they are comagmatic, and that they were emplaced at shallow depth.

\section{GEOCHEMISTRY}

Samples analyzed by neutron activation analys is show a narrow range of major and minor element abundances that is typical of andesites and diorites. These rocks are distinguished from other ande- 
sites by lower abundances of $\mathrm{Fe}, \mathrm{Na}, \mathrm{Cr}, \mathrm{Sc}$, and $\mathrm{Co}$; and by higher abundances of $\mathrm{Ba}, \mathrm{Th}, \mathrm{Sm}, \mathrm{Eu}$, and $\mathrm{Hf}$. Comagmatism of the analyzed samples is suggested by the small variation in Sc and the light rare earth elements, and by the covariation of $\mathrm{Fe}$ and $\mathrm{Co}$, and $\mathrm{Fe}$ and $\mathrm{Sc}$. As is typical of andesites, these rocks show only minor fractionation. The andesite porphyry of Bull-of-the-Woods, the quartz diorite of Twin Lakes, and the diorite of Elk Lake Creek suites each show small differentiation trends within their respective samples. The diorite of Elk Lake Creek is the least differentiated suite of rocks analyzed, while the quartz diorite of Twin Lakes is the most differentiated suite. Other lithologies are intermediate between these two suites, and do not show a clear cut order of differentiation.

\section{EMPLACEMENT OF INTRUSIONS}

Cross-cutting relations between all intrusive lithologies have not been found, thus a complete ordering of emplacement cannot be made. The pyroxene andesite porphyry of Big STide Mountain has no glomeroporphyritic clusters of plagioclase, but nonetheless appears to be comagmatic with the other units. It was probably emplaced first, before the melt cooled sufficiently for the clusters to form. The andesite porphyries of Mother Lode Mountain and Bu17-of-the-Woods are intruded by other more coarsely grained units. These andesite porphyries were emplaced after the pyroxene andesite porphyry. The dacite porphyry has the largest glomeroporphyritic clusters of any unit, but shows no field relationship with other units; its emplacement order is unknown. The Pansy Mountain quartz diorite intrudes 
the Mother Lode andesite porphyry, and is less differentiated than Twin Lakes quartz diorite porphyry; thus, it may have been intruded before the Twin Lakes unit. The diorite of Elk Lake Creek is the least differentiated unit in the area, but it bears no field relation to any other unit. Its emplacement order is unknown. The last unit to be emplaced is also the most differentiated; the quartz diorite porphyry of Twin Lakes intrudes the andesite porphyry of Buil-of-the-Woods, and appears to have followed the other units to its present position.

\section{MECHANISM OF INTRUSION}

Contacts between the host and intrusive rock place constraints on a probable mechanism of intrusion without actually defining that mechanism. The absence of host xenoliths in the intrusive rocks indicate that stoping was not a mechanism. Nor was the magma squeezed into the wall rocks; however, the intrusives may have been injected jinto the host rock; fissures for the magma to move through may have been created by forceful injection. Zones of brecciation found in the host rock at intrusive contacts do not extend beyond the intrusives as faults or fissures, and so these zones probably occurred when the intrusion was emplaced. The host rock is also deformed near the intrusions, suggesting the magma was able to force its way into the host rock, making space for itself at the expense of the host. Diverse trends and distribution of intrusives argue against dilatency in the host rock. In summary, the intrusions appear to be emplaced by forcefur injection along zones of weakness. 
BATHOLITH

Contact metamorphism of the host rock in the study area, and the absence of regional structures in the study area suggests a stock underlies the study area at a greater depth than $1000 \mathrm{~m}$. 


\section{REFERENCES CITED}

Anierican Association of Petroleum Geologists, 1960, Code of stratigraphic nomenclature AAPG Bulletin, v. 45 , no. 5 pp. $645 \cdots 665$.

Carmichael, I. S., F. H. Turner, and J. Verhoogen, 1.974, Igneous petrology: McGraw-Hill, New York, 739 p.

Deer, W. A., R. A. Howie, and J. Zussman, 1966, An introduction to the rock-forming minerals: Longman, London, 528 p.

Durre11, C., 1949, A key to the common rock-forming minerals in thin section: Freeman, San Francisco, $17 \mathrm{p}$.

Dyhrman, R. F., 1975, Geology of the Bagby Hot Spring area, Clackmas and Marion counties, Oregon: Master's thesis, Oregon State University, $79 \mathrm{p}$.

Frey, F. A., B. W. Chappe11, and S. D. Roy, 1978, Fractionation of rare-earth elements in the Toulumne intrusive series, Sierra Nevada batholith, California: Geology, v. 6, pp. 239-242.

Goidrich, S. S., S. B. Treves, N. H. Suhr, and J. S. Stuckless, 1975, Geochemistry of the Cenozoic volcanic rocks Ross Island and Vicinity, Antarctica: Journal of Geology v. 83, no. 4, pp. 415435.

Gordon, G.E., Randel, K., Goles, G.G., Corliss, J.B. Beeson, M.H., Oxley, S.S., 1968, Instrumental activation analysis of standard rocks with high resolution gamma-ray dectors: Geochimica Cosmochimica Acta, V. 32, pp. 369-396.

Gunn, B. M., 1974, Systematic petrochemical differences in andesite suites: Bulletin Volcanologique, v. 38, pp. 481-490.

Hyndman, D. W., 1972, Petrology of Igneous and metamorphic rocks: McGraw-Hil1, New York, 533 p.

Jackson, D. 1970, Textbook of 1ithology: McGraw-Hi11, New York, 484 p.

McBirney, A. R., 1968, Petrochemistry of the Cascade Andesite Volcanos: Oregon Department of Geology and Mineral Industries Bulletin, v. 62, pp. 101-108.

Moir, W. H., C. Maser, and J. F. Franklin, 1973; Bagby Research natural area: United States Forest Service, $12 \mathrm{p}$. 
Peck, D. L., A. R. Griggs, H. G. Schlicker, F. G. Wells, and D. M. Dole, 1964, Geology of the central and northern parts of the Western Cascade range in Oregon: United States Geological Survey, Professional Paper 440, 56 p.

Ringwood, A. E., 1975, Composition and petrology of the earth's mantie: McGraw-Hill, New York, 618 p.

Smith, E. I., 1978, Precambrian rhyolites and granites in southcentra] Wisconsin: field relations and geochemistry: Geological Society of America Bulletin v. 89, pp. 879-895.

Streckeisen, A. L., 1973, Classification and nomenclature recommended by the IUGS subcommission on the systematics of igneous rocks: Geotimes, v. 18, no. 10, pp. 26-30.

Taylor, S. R., and A. J. R. White, 1966, Trace element abundances in andesite:- Bulletin Volcanologique, v. 20, pp. 177-194.

Thayer, T. P., 1937, Petrology of later Tertiary and Quaternary rocks of the northcentral Cascade Mountains in Oregon: Geological Society of America, Bulletin 48, pp. 1611-1651.

Thayer, T. P., 1939, Geology of the Salem Hills and the North Santiam River Basin, Oregon: Oregon Department of Geology and Mineral Industries Bulletin 15, $40 \mathrm{p}$.

Tobi, A. C., and Herbert Kroll, 1975, Optical determination of the An-content of plagioclase twinned by Carlsbad-law: American Journal of Science, v. 275, pp. 731-736.

Hel1s, F. G. and D. L. Peck, 1961, Geologic map of Oregon west of the 121st Meridian: United States Geological Survey.

Winchester, J. A. and P. A. Gloyd, 1977, Geochemical discrimination of different magma series and their differentiation products using immobile elements: Chemical Geology v. 20, pp. 325-343. 


\section{APPENDIX}

Sample Number

SDP-1

SDP-2

BSA-3

MLA-4

SDP-5

BWA-6

TL-8

MLA-9

MLA-10

MLA- 77

MLA-12

PM-13

EL-15

TL-16

TL-17

BWA-18

$E L-20$

BWA-21

BWA-22

EL-23

BSA-25

BSA-26
Location

Elevation

NE NW SW Sec. 5, T. 8. S., R. 6 E.

$4400^{\prime}$

NW SW NW Sec. 17, ",

$4840^{\prime}$

SW NE NE Sec. 25, ", "

$4860^{\prime}$

NE SW SE Sec. 20, ", " "

$4870^{\prime}$

NW NE NW Sec. 8, " , "

SE NW NE Sec. 17, " , "

SW NW NE Sec. 30, " , "

SE NW SW Sec. 20, ", "

NW NW SW Sec. 20, " , "

SE SW NE Sec. 19, ", "

SW SW NE Sec. 19," , "

NE SW NE Sec. 19, " , "

SW SW SE Sec. 14, ", "

NW SE NE Sec. 16," " "

NW SW NE Sec. 16, "; "

NW SW NE Sec. 16, ",

SE SW SW Sec. 21, " , "

SW SW SW Sec. 15, ", "

SE SE NE Sec. 18, " , "

NW SW SW Sec. 27, "

NW NE NW Sec. 16, ", "

SE SE SH Sec. 9, " , " $5372^{\prime}$

$5523^{\prime}$

$4240^{\prime}$

$4960^{\prime}$

$4880^{\prime}$

$5190^{\circ}$

$5040^{\prime}$

$5050^{\prime}$

$2550^{\prime}$

$4480^{\prime}$

$4490^{\prime}$

$4880^{\circ}$

$4400^{\prime}$

$4390^{\prime}$

$4640^{\prime}$

$2800^{\prime}$

$4470^{\circ}$

$5180^{\prime}$ 
BSA-27

BSA-29

BSA-31

BSA-32

TL-34
SW SE SE Sec. 9, T. 8 S., R. 6 E. NE SW SW Sec. 9, SE SE SE Sec. 9, SW NW SW Sec. 10, NE NW NW Sec. 22 ,

" , 1

", 1

",

II $5060^{\prime}$

$4200^{\prime}$

$5120^{\prime}$

$4880^{\prime}$

$4640^{\prime}$ 